\section{Smith ScholarWorks}

$12-2004$

\section{Unconformities and Age Relationships, Tongue River and Older Members of the Fort Union Formation (Paleocene), Western Williston Basin, U.S.A.}

\author{
Edward S. Belt \\ Amherst College \\ Joseph H. Hartman \\ University of North Dakota \\ John A. Diemer \\ University of North Carolina at Charlotte \\ Timothy J. Kroeger \\ Bemidji State University \\ Neil E. Tibert \\ Smith College
}

See next page for additional authors

Follow this and additional works at: https://scholarworks.smith.edu/geo_facpubs

Part of the Geology Commons

\section{Recommended Citation}

Belt, Edward S.; Hartman, Joseph H.; Diemer, John A.; Kroeger, Timothy J.; Tibert, Neil E.; and Curran, H. Allen, "Unconformities and Age Relationships, Tongue River and Older Members of the Fort Union Formation (Paleocene), Western Williston Basin, U.S.A." (2004). Geosciences: Faculty Publications, Smith College, Northampton, MA.

https://scholarworks.smith.edu/geo_facpubs/44

This Article has been accepted for inclusion in Geosciences: Faculty Publications by an authorized administrator of Smith ScholarWorks. For more information, please contact scholarworks@smith.edu 


\section{Authors}

Edward S. Belt, Joseph H. Hartman, John A. Diemer, Timothy J. Kroeger, Neil E. Tibert, and H. Allen Curran 


\title{
Unconformities and age relationships, Tongue River and older members of the Fort Union Formation (Paleocene), western Williston Basin, U.S.A.
}

\author{
Edward S. Belt ${ }^{1 *}$, Joseph H. Hartman ${ }^{2}$, John A. Diemer ${ }^{3}$, Timothy J. Kroeger ${ }^{4}$, Neil E. Tibert ${ }^{5}$, and
}

H. Allen Curran ${ }^{5}$

${ }^{1}$ Department of Geology, Amherst College, Amherst, MA 01002, U.S.A.

${ }^{2}$ Department of Geology and Geological Engineering, and Energy \& Environmental Research Center, University of North Dakota, Grand Forks, ND 58202, U.S.A.

${ }^{3}$ Department of Geography and Earth Sciences, University of North Carolina, Charlotte, NC 28223, U.S.A.

${ }^{4}$ Department of Biology and Geology, Bemidji State University, Bemidji, MN 56660, U.S.A.

${ }^{5}$ Department of Geology, Smith College, Northampton, MA 01063, U.S.A.

*Author to whom correspondence should be addressed: esbelt@amherst.edu.

\section{ABSTRACT}

An unconformable relationship is observed within the Paleocene Fort Union Formation in the western Williston Basin at the contact between the Tongue River Member and the underlying Lebo and Ludlow Members. Isotopic dates and pollen biozone data reported here are integrated with previously published data. A new correlation of these facies results in a revised history of localized depositional and tectonic events. One unconformity occurs at this lithological contact in the Pine Hills (PH), Terry Badlands (TB), and Ekalaka (E) areas west of the Cedar Creek anticline (CCA), and another unconformity occurs at the same lithological contact in the Little Missouri River (LMR) area east of the CCA. The two unconformities differ in age by about two million years. The older is the $\mathrm{U}_{2}$ and the younger is the $\mathrm{U}_{3}$, which initially were recognized in the Ekalaka area of southeastern Montana (Belt et al., 2002). The $U_{2}$ crops out in the TB, PH, and $\mathrm{E}$ areas, where at least $85 \mathrm{~m}$ of Tongue River strata bearing palynomorphs characteristic of biozone P-3 are found above the unconformity. Radiometric dates from strata (bearing palynomorphs characteristic of biozone P-2) below the $\mathrm{U}_{2}$ range in age from 64.0 to $64.73 \mathrm{Ma}$. The $\mathrm{U}_{2}$ unconformity west of the CCA thus occurs in strata near the base of the lower P-3 biozone.

The $\mathrm{U}_{3}$ crops out in the LMR area (east of the CCA), where only $13 \mathrm{~m}$ of strata characterized by the P-3 pollen biozone occur above it. Radiometric dates from an ash $<1 \mathrm{~m}$ above the $\mathrm{U}_{3}$ in that area range in age from 61.03 to 61.23 $\mathrm{Ma}$, and the P-3/P-4 pollen biozone boundary is located $13 \mathrm{~m}$ above the ashes. The $\mathrm{U}_{3}$ thus occurs in strata characterized by upper parts of the P-3 pollen biozone east of the CCA. The $\mathrm{U}_{3}$ is also identifiable in the middle of the ca. 200 m-thick Tongue River Member west of the CCA, where mammal sites 40 to $80 \mathrm{~m}$ above it are Tiffanian-3 in age. The strata below this unconformity are tilted gently to the northwest; strata above the unconformity are flat lying. This mid Tongue River unconformity probably correlates with the unconformity at the base of the Tongue River Member in the LMR area east of the CCA, where a Ti-2 mammal site (the "X-X" locality) occurs $<10 \mathrm{~m}$ above it.

Depositional and tectonic events can be summarized using North American Mammal Age nomenclature as a relative time scale. From latest Cretaceous through Puercan time, paleodrainage was toward the east or southeast, in the direction of the Cannonball Sea. The Black Hills did not serve as an obstruction at that time. During early Torrejonian time, the Miles City arch (MCA) and Black Hills were uplifted and partially eroded, leading to the $\mathrm{U}_{2}$ unconformity. When deposition resumed, paleodrainages shifted to a northeasterly course. During middle and late Torrejonian time, facies of the lower Tongue River ("Dominy") sequence and the Ekalaka Member of the Fort Union Formation were 
deposited in the middle of a subbasin between the MCA and the CCA. Simultaneously, smectite-rich components of the Ludlow Member were being deposited east of the CCA. During latest Torrejonian time, uplift of the Black Hills tilted the "Dominy" sequence toward the northwest and local erosion led to the $\mathrm{U}_{3}$ unconformity. Following this tilting, during Tiffanian time, deposition of the upper Tongue River ("Knobloch") sequence shows continuity from western North Dakota across eastern Montana and into the northern Powder River Basin.

KEY WORDS: mammal ages, Paleocene, pollen biozones, radioisotopic ages, stratigraphy, tectonics, unconformities, Williston Basin.

\section{INTRODUCTION}

This report proposes a new regional correlation of early to middle Paleocene strata in part of the western Williston Basin. The basic data come from closely spaced stratigraphic sections measured within specific, though widely scattered, study areas (viz. SB, PH, TB, E, and LMR, Fig. 1). This is the first attempt to correlate these strata over such a broad region. Correlations are accomplished by integrating new and published bio- and chronostratigraphic data with new stratigraphic sections and recently published geologic maps.

Paleocene strata in the western Williston Basin extend from western North Dakota to eastern Montana, and thence to the Powder River Basin in Wyoming (Fig. 1). Although there is no consistent agreement on where the two basins meet, the axis of the Miles City arch (MCA, Fig. 1) and its extension southeast to the Black Hills of South Dakota is used here.

Previous research has not focused on regional correlation as a specific objective for these Paleocene strata (e.g., Belt et al., 1984; Belt et al., 1992). The Ekalaka report by Belt et al. (2002) shows weaknesses that were the result of our extrapolating a well-researched area into imperfectly understood areas to the north and northeast. It can now be shown, for example, precisely which parts of figure 2 of Belt et al. (2002) need modification.

All prior researchers made the assumption that the strata west of the Cedar Creek anticline (CCA, Fig. 1) correlated directly with strata east of the CCA (Fig. 2A and $2 \mathrm{~B})$. Although pollen and radiometric dating in North Dakota have been well established for years (e.g., Warwick et al., 1995), similar dating in eastern Montana has not been done until recently (Tibert et al., 2001; Belt et al., 2002). In addition, most workers (e.g., Cherven and Jacob, 1985; Belt et al., 1984, 1992; Daly et al., 1992; Flores et al., 1999) assumed that there are no significant unconformities within the Fort Union Formation. Two new unconformities, the $\mathrm{U}_{2}$ and $\mathrm{U}_{3}$, documented in the Ekalaka area (E, Fig. 1; Belt et al., 2002), recently showed the fallacy of that assumption.

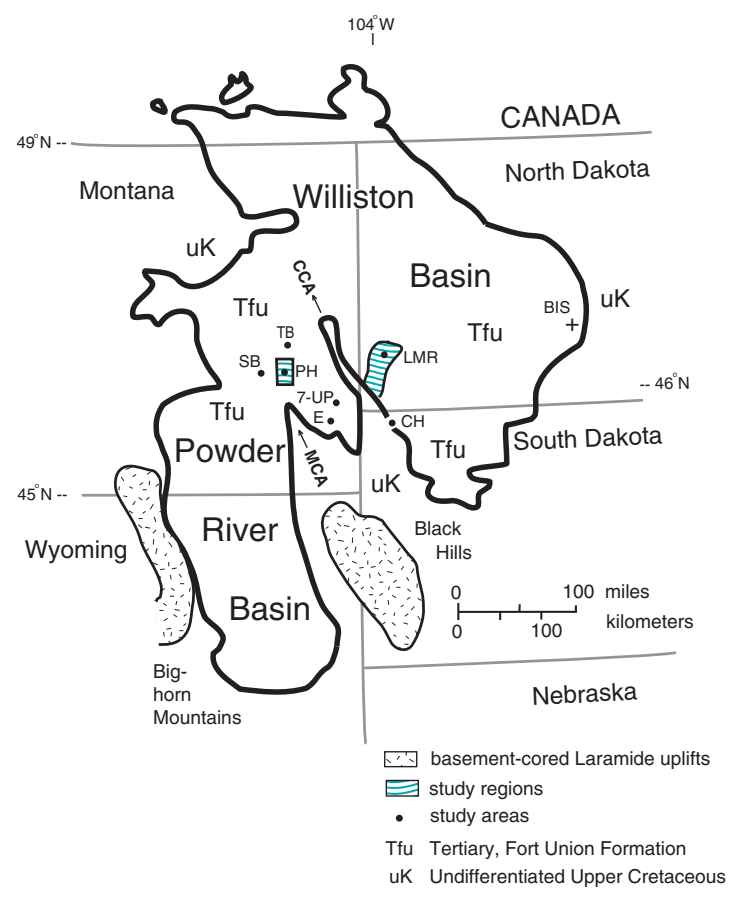

Figure 1. Outline of Williston and Powder River Basins as defined approximately by Cretaceous-Paleocene contact. Boundary between Powder River and Williston Basins is along axis of Miles City Arch. Abbreviations: MCA, Miles City arch; CCA, Cedar Creek anticline; SB, Signal Butte area at Miles City; PH, Pine Hills area near Locate (specific sections at dot are in Fig. 5); TB, Terry Badlands area near Terry; LMR, Little Missouri River area (specific sections at dot are in Figs. 9 and 10); E, Ekalaka area; 7-UP, Seven Up Butte, $14 \mathrm{~km}$ southwest of Willard, MT; and CH, Cave Hills area, near Buffalo, SD.

The present report is concerned mainly with Paleocene strata that crop out: (1) between the two Cretaceouscored uplifts, the CCA and the MCA (SB, TB, PH, E, and 7-UP, Fig. 1); and (2) east of the CCA in the area of the Little Missouri River (LMR, Fig. 1). Evidence is presented first for an unconformity at the base of the Tongue River Member; this boundary also coincides with a major facies change (Fig. 2). Later, when bio- and chronostratigraphic evidence for dating is presented, it becomes apparent that the facies change and its associated 

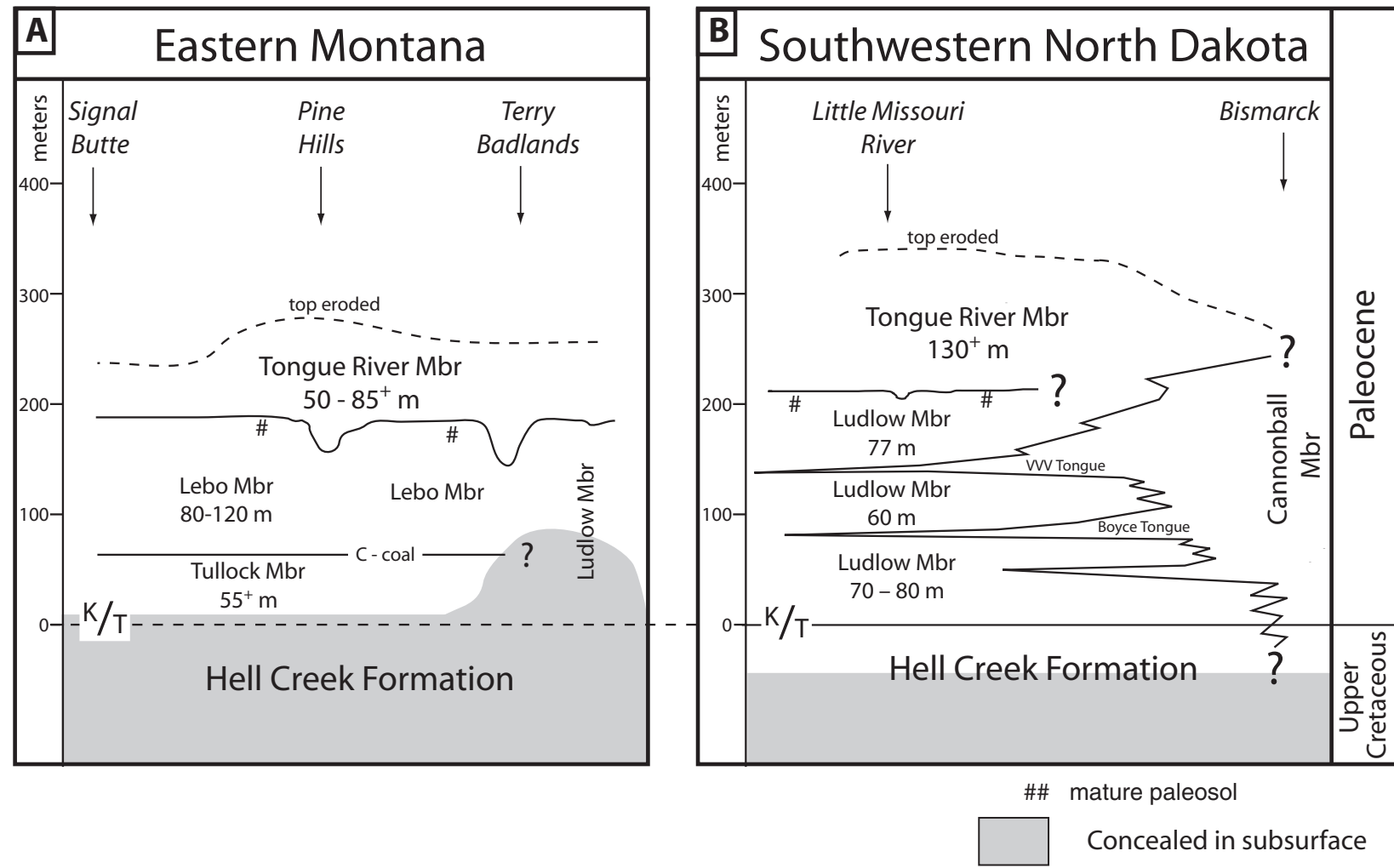

Figure 2. Members of Paleocene Fort Union Formation that overlie Upper Cretaceous Hell Creek Formation. Thickness of each member based on surface measurements. Cannonball Member and its tongues within Ludlow Member are entirely of marine origin. Ludlow, Lebo, and Tullock Members are of fluvial and lacustrine origin. Tongue River Member is largely of fresh water origin, but with lower $85 \mathrm{~m}$ in (A) containing at least five thin, marine-influenced beds (Belt et al., submitted). Basal contact of Tongue River Member contains paleovalleys that cut through older, mature paleosols. Montana (A) and North Dakota (B) districts, on opposite sides of Cedar Creek anticline, are juxtaposed here to allow critical examination of their correlation.

unconformity resulted from two uplift events, of different ages. The older uplift event was first observed west of the CCA, and the younger event was first observed east of the CCA. These two unconformities can now be correlated more widely than previously thought (Belt et al., 2002). Finally, analysis of pollen biozones and mammalian ages shows that evidence for the older unconformity also exists east of the CCA and that evidence for the younger unconformity also exists west of the CCA.

\section{STRATIGRAPHY}

\section{Introduction}

Five of the six members of the Paleocene Fort Union Formation are shown in Figure 2. The sixth, the Ekalaka Member (Belt et al., 2002), occurs south of the Figure 2 line of correlation. Throughout the present report, graphical logs are presented that document the stratigraphic position of specific pollen biozones, sources of radioistopic dates, and mammalian tooth-bearing sites. These dates are also related to key coal beds (only a few of which are shown on Fig. 2) and to important boundaries among various members of Fort Union Formation.

\section{Paleogeographic Maps}

A series of paleogeographic maps (Belt, 1993, figs. 9-12) shows the specific structural elements that influenced Upper Cretaceous and Paleocene facies in western parts of the Williston Basin. These elements are the Miles City arch, Cedar Creek anticline (MCA, CCA, Fig. 1), and Black Hills.

During latest Cretaceous and earliest Paleocene time, channel-belt deposits showed directions of trunk paleodrainages that trended to the southeast. The ancestral Black Hills was thus unlikely to have been present at that time. This is consistent with a southeast drainage direction 
in the Hell Creek Formation (Belt et al., 1997, fig. 15). The southeastly direction changed to one flowing to the northeast by the time of C-coal deposition (Fig. $2 A$ ) and is one type of evidence for uplift of the Black Hills (Belt, 1993; Belt et al., 2002). Whether flowing southeasterly or northeasterly, the ultimate destination of these rivers was the Cannonball Sea that lay to the east in central North and South Dakota. That sea is known to have persisted from Late Cretaceous time through the early and middle Paleocene (Hartman and Kirkland, 2002; Hoganson and Murphy, 2002).

\section{Cannonball Member}

The Cannonball Member is confined to North and South Dakota and consists largely of shale with intercalations of fine-grained sandstone. Marine fossils (Cvancara, 1965, 1976) are common throughout the succession, and neither freshwater coal beds nor nonmarine shell beds have been identified in it. The Cannonball Member intertongues to the west with the Ludlow Member.

Informally defined marine tongues of the Cannonball Member were separated from the deltaic deposits of the Ludlow Member in the Little Missouri River area (Fig. 2B) by Clayton et al. (1977), and more recently named by Hartman (1993). These tongues, the Three V and the Boyce, can be identified on the basis of marine fossils studied by Cvancara (1965), Van Alstine (1974), and Kroeger and Hartman (1997).

\section{Ludlow and Lebo Members}

Strata of the Ludlow Member consist of unconsolidated mud and sand with many thin, and a few thick, lignitic beds. Most of the Ludlow Member is dark gray to somber brown in color, which reflects the dominance of smectite clay minerals (Belt et al., 1985). About six, 2 mto $4 \mathrm{~m}$ - thick, light-yellow sand beds occur in the 190-195 $\mathrm{m}$ of strata (Belt et al., 1984). In contrast to the rest of the Ludlow strata, these light-yellow facies are dominated by kaolinite and illite clay minerals.

The Ludlow Member includes all strata above the Hell Creek Formation and below the Tongue River Member in the Little Missouri River and Ekalaka areas (LMR, E, Fig. 1). The name is not used to the north and northwest of Ekalaka, where similar facies are subdivided into the Lebo and Tullock Members by presence of the C-coal zone (Fig. $2 A$ ). That coal does not occur in the Ludlow Member.

Ludlow strata contain six prominent coal beds, two of which are associated with tongues of the marine
Cannonball Member. The T-Cross coal bed is thick, confined to a small area near the Little Missouri River (Belt et al., 1984, fig. 9), and is directly overlain by the Boyce Tongue. The younger Oyster coal bed is thin and widespread, and it has been used to distinguish an older Facies A from a younger Facies B of the Ludlow Member (Belt et al., 1984). The term Marmarth Delta has been used (Cherven and Jacob, 1985; Kroeger and Hartman, 1997) to characterize Ludlow facies including the two Cannonball Tongues, as well as any other marine-influenced bed more recently discovered within the Ludlow Member. The term Slope Formation (Clayton et al., 1977; Hartman, 1993), which was defined as consisting of all nonmarine strata lying between the two marine tongues and below the base of the Tongue River (or Bullion Creek) Member, ought to be set aside because marine beds have been found recently in the lower $20 \mathrm{~m}$ of the Tongue River Member (Belt et al., submitted) and in the Ludlow Member below the Boyce Tongue (Hartman and Butler, 1995).

\section{Lower Part of Tongue River Member}

Lower parts of the Tongue River Member consist of mud and sand that are dominated by kaolinite and illite clay minerals. For this reason, Tongue River lithologies are light colored and easily distinguished from the older Lebo and Ludlow Members, which are dominated by smectite clay minerals. These differences in clay minerals are used here for identifying paleovalleys at the stratigraphic contacts between Tongue River and Lebo or Ludlow Members.

The lower part of the Tongue River Member contains dozens of 2 to 4 m-thick, coarsening-upward sequences of mud and fine-grained rippled sand and sandstone. These laterally extensive sequences often culminate in thin beds of coal and/or sands containing freshwater mollusks. Very thin bleached beds of siliciclastics and rare silcrete are found in these strata.

\section{Criteria for Recognizing Paleovalleys}

The following three elements, listed as a time sequence, are useful for recognizing paleovalley deposits and hence, by definition, for determining the existence of an unconformity at base of the Tongue River Member.

(1) Long-term deposition of Lebo and Ludlow sediments ceases due to a drop in relative base level (i.e., sea level). Rivers dissect the exposed terrain, producing valleys that show a dendritic drainage pattern. Deep weath- 
ering develops on the interfluves between the channels and produces a mature paleosol. The paleosol consists of bleached mud and sand beds that often include silcrete. The paleosol occurs at the top of the Lebo and Ludlow deposits, directly below Tongue River strata, and contains abundant large roots traces. It has been interpreted as a mature paleosol (Wehrfritz, 1978; Christiansen, 1984; Simon-Coinçon et al., 1996; Gregory Retallack, personal communication, 1997). Thin Tongue River deposits occurring beyond the region of the paleovalleys overlie the paleosol deposits and are correlated directly into the upper paleovalley sequence.

(2) Unusual facies of Tongue River strata backfill the valleys that were cut into the underlying strata of the Lebo or Ludlow Members. The thickness of these deposits can be 30 to $40 \mathrm{~m}$, which exceeds the thickness of normal single-storeyed channel deposits of autogenic origin (Diemer and Belt, 1991). Incised channel deposits consist of single storeys that contain a fining-up succession beginning with cross-bedded (trough and tabular), fine- to medium-grained sand of fluvial origin. The top of the succession culminates in lateral 'spill-over' deposits of mud and coal beds that blanket the region outside the incised valley. These blanket deposits commonly include marine-influenced burrow beds of rippled, fine-grained sand and sandstone and muddy beds containing marine diatoms. They are interpreted as occurring at the end of transgression and at the beginning of highstand conditions.

(3) Normal Tongue River sedimentation then commences.

\section{Lebo-Tongue River Contact West of Cedar Creek Anticline}

\section{Terry Badlands Area (Locality TB; Figs. 1-4)}

This study area lies at the eastern end of the Terry Badlands Wilderness Area, north of the Yellowstone River and $4 \mathrm{~km}$ north of I-94 at Terry, Montana (TB, Fig. 1). The contact between the Lebo and the Tongue River Members is well exposed for many tens of kilometers to the southwest of this study area (Heffern, 1981; Belt et al., 1992; Vuke and Colton, 2003). It is easily recognized by the change in clay mineralogy (and hence weathering and color) and by the presence of a thin contact coal bed (Parker and Andrews, 1939), which underlies thin bleached beds containing marine diatoms (Belt et al., submitted).
Seven stratigraphic sections were measured, of which three are shown on Figure 3. The Terry II section is approximately equidistant between the Paleovalley Section (PV on Fig. 3) and the Mushroom Café Section, about 600 $m$ each way. A burrow bed, designated the high-diversity ( Hi. D. ) burrow bed, was used as a datum for correlation. A $60 \mathrm{~cm}$-thick marine diatom bed below it consists of bright white, silty mud.

The burrow bed, less than $2 \mathrm{~m}$ thick, consists of ripple-laminated, fine- to medium-grained sandstone. It contains features indicative of marine influence, identified as burrows, Diplocraterion, Monocraterion, Skolithos linearis, Teichichnus, and Thalassinoides. A 2 m-thick bed of medium-grained ripple- and cross-bedded sandstone cuts down into the burrow bed (Fig. 3). This younger bed contains a freshwater bivalve, Plesielliptio, in life position

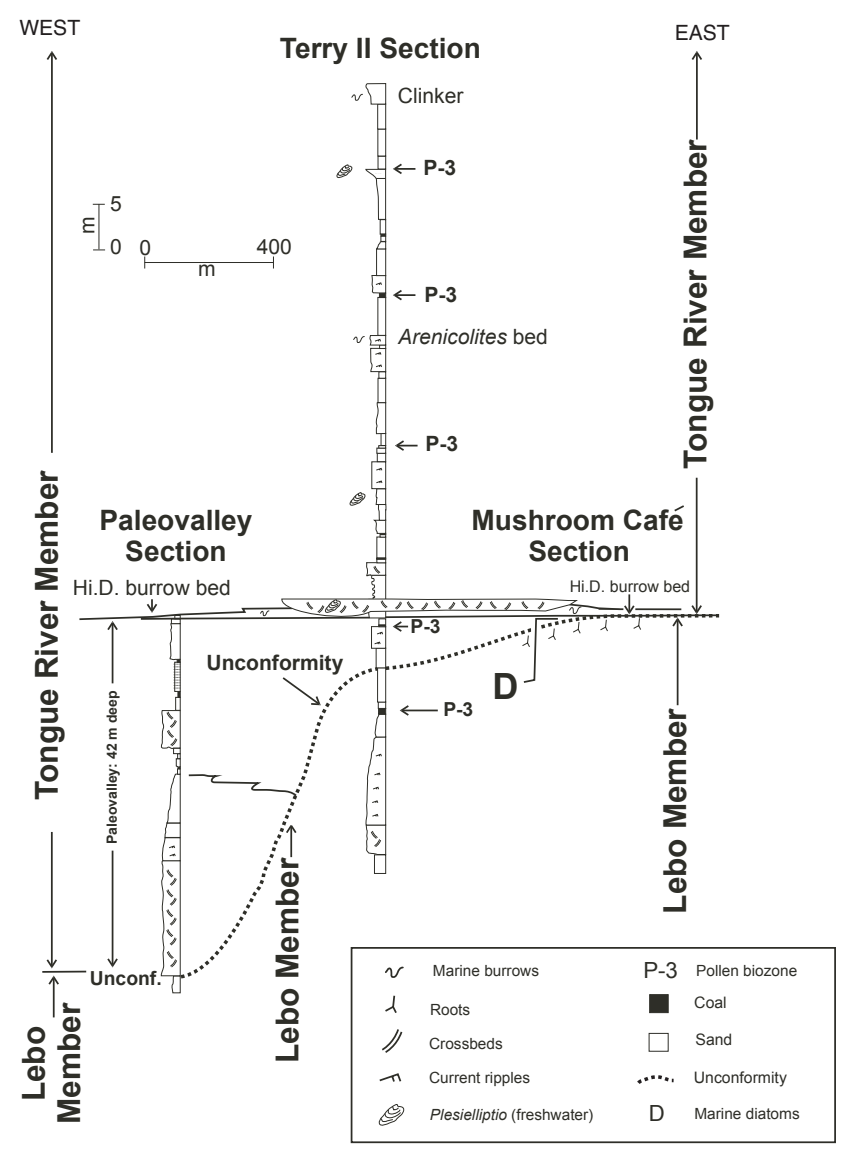

Figure 3. Paleovalley between Tongue River and Lebo Members, Terry Badlands, near Terry, Montana. Paleovalley depth $(42 \mathrm{~m})$ is measured from base of Hi. D. ("high diversity") burrow bed to base of sand in incised valley fill. Paleoflow direction (from cross-bedded sand) is to south. Pollen was collected in Terry II Section only. 


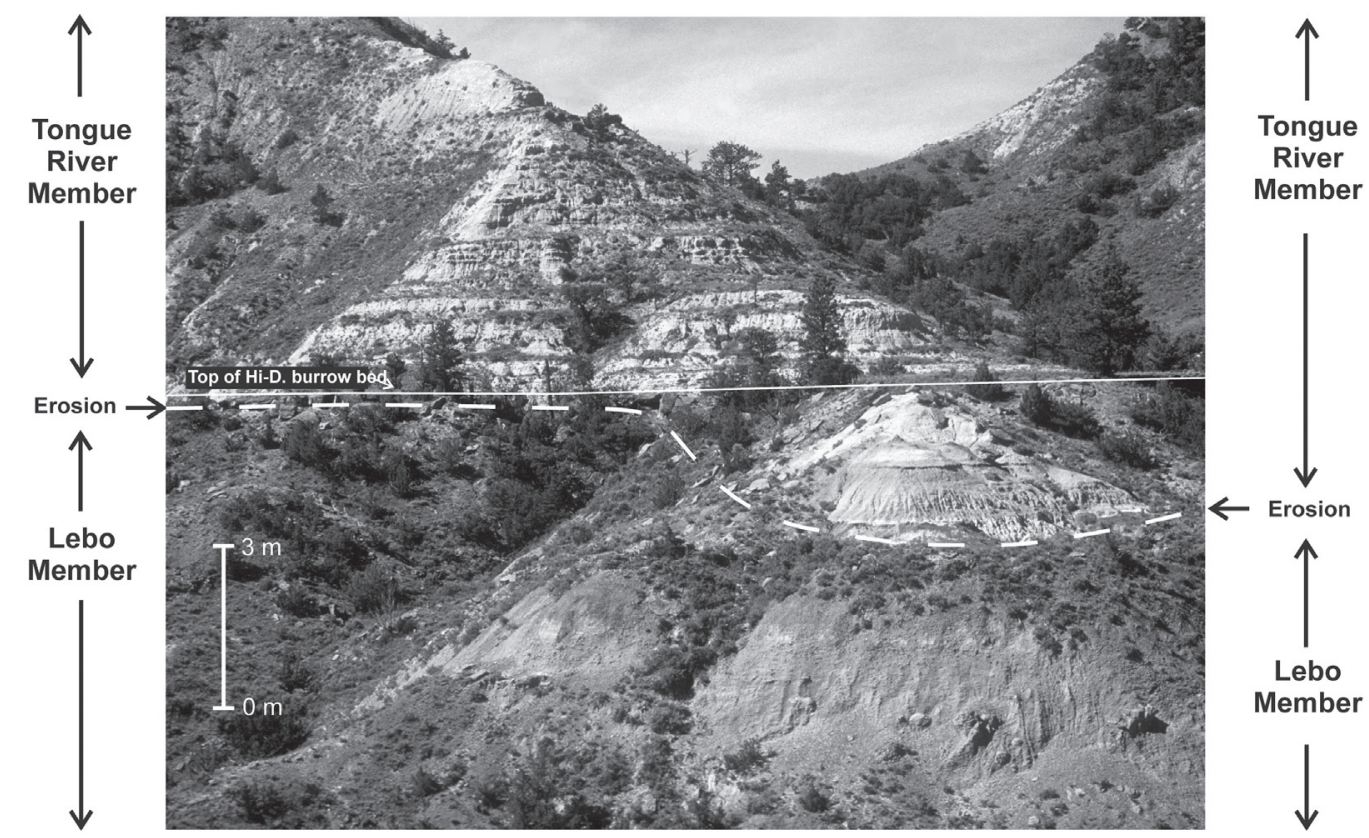

Figure 4. An eastern tributary of Tongue River paleovalley shown in Figure 3. Note on left that "Hi. D. burrow bed" rests directly on Lebo Member, but in right foreground, $3 \mathrm{~m}$ of Tongue River incised valley fill occur below it. This tributary joins main paleovalley beyond buttes in background.

(Belt et al., submitted). This complex of deposits indicates that fresh water conditions followed the brief marineinfluenced conditions.

Figure 3 shows that a 42 m-thick, Tongue River deposit is deeply incised into typical strata of the Lebo Member. All criteria for the presence of a paleovalley, listed earlier, apply to the Tongue River-Lebo contact in the Terry Badlands area. The lowest depositional unit in the paleovalley succession consists of $14 \mathrm{~m}$ of yellow, crossbedded, fine- to medium-grained, unlithified sand. This sand is overlain by $10 \mathrm{~m}$ of strata that form a fining-upward sequence grading from rippled sand to mud. The lateral margins of this deposit (i.e., the sidewalls) are exposed by Holocene erosion along the axis of the paleovalley. One can stand on basal yellow sand of undisputable Tongue River lithology at the bottom of the paleovalley and look laterally at older muds of the Lebo Member.

A small, incised valley (Fig. 4) developed when the main channel was being cut. The high-diversity burrow bed that lies $42 \mathrm{~m}$ above the base of the main channel lies only $3 \mathrm{~m}$ above the base of this side valley (Fig. 4, center of view). In this view, the burrow bed extends beyond the edge of the side channel to overlap darker strata of the Lebo Member on either side. Figure 4 is viewed in the direction of flow (to the southwest). The paleovalley side channel shown here joins the main paleovalley channel on the other side of the ridge in the background. Note the narrowness of the side-channel incision. No mature paleosol developed in Lebo facies at this locality.

A large outcrop of white (bleached) strata with silcrete beds occurs 10 to $11 \mathrm{~km}$ west of the Terry Badlands study area along a road called the Calypso Trail (Sec. 13, NE 1/4, T. 12 N., R. 49 E., McClure Reservoir quadrangle, and Sec. 18, NW 1/4, T. 12 N., R. 50 E., Calypso quadrangle). These outcrops were included in basal strata of the Tongue River Member (Susan Vuke, personal communication, November, 2002; E. L. Heffern, personal communication, 2004), but we disagree. More probably they occur at the top of the Lebo Member below the contact with the overlying Tongue River Member. No paleovalley was seen in the area of silcrete.

\section{Pine Hills Area (Locality PH, Figs. 1, 2, 5, and 6)}

Sections of Tongue River and Lebo strata exposed in the badlands west of the Powder River, near Locate, Montana, are shown in Figures 5 and 6. They include the upper $60 \mathrm{~m}$ of the Lebo and the lower $95 \mathrm{~m}$ of the Tongue River Members. No complete thickness of the Tongue River Member is found in eastern Montana (Fig. 
2). The straight-line distance between Section PH-B-31 and Section PH-B-52 is $<9 \mathrm{~km}$ (Fig. 5).

The same lithologic change of clay minerals, mentioned earlier in the Terry Badlands, is used to determine the Lebo-Tongue River contact. Note in Figure 6 that some strata dominated by kaolinite and illite are found below the contact, but none occurs above it. A thin white bed, lacking root traces, lies directly above the contact coal zone. It is widespread in the Pine Hills area and should be checked for marine diatoms; examination of samples along the North Strevelle road (Fig. 5) failed to reveal any.

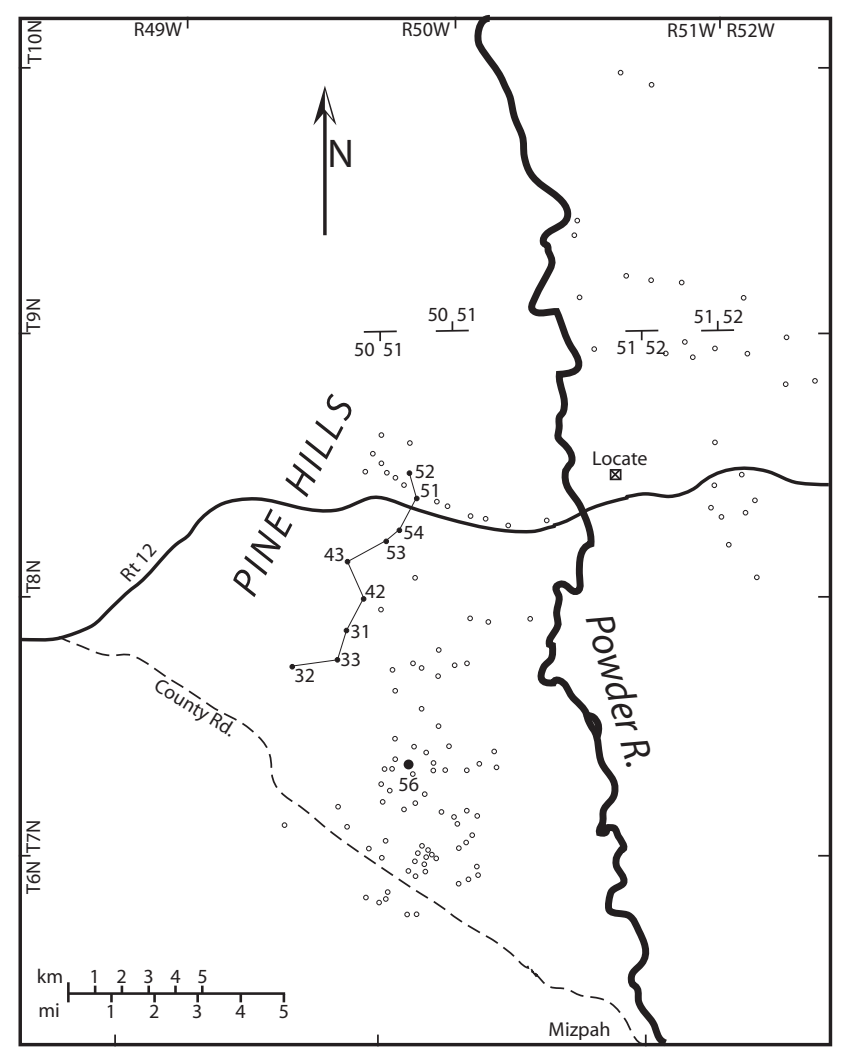

Figure 5. Location of measured sections shown in Figure 6. Pine Hills study area is west of Powder River and between Montana Route 12 and County Road to Mizpah (now an abandoned $\log$ school). Locality 56 refers to Figure 7.

Section PH-B-33 (Fig. 6) demonstrates a lithologic composition typical of the Tongue River Member that is incised into smectite-dominated units of Lebo strata by as much as $32 \mathrm{~m}$. Near the base of this deposit, strata of the Tongue River cut across the two thin Lebo coal beds. This is an incised valley fill or a paleovalley, and it exhibits each of the relevant criteria listed earlier.

The oldest sediments in the incised deposit of Section PH-B-33 begin with $19.5 \mathrm{~m}$ of trough and tabular, crossbedded sand with paleocurrent trends to the north and northeast. This is the base of a fining-upward sequence. At the top are two coal beds, the upper one being $1.2 \mathrm{~m}$ thick. The basal burrow bed (bbb and also \#1, Fig. 6) lies $4 \mathrm{~m}$ above this coal. It consists of fine-grained, rippled sand that contains Skolithos linearis, Teichichnus, and Rhizocorallium. No body fossils were found in this basal burrow bed ("bbb") in Section PH-B-33, but fresh-water bivalves and gastropods are in sand cut into the "bbb" in Sections PH-B-42 and 43 to the north.

Finally, silcrete beds (Fig. 7) are found in strata normal for upper parts of the Lebo Member below the contact coal zone in Section PH-B-56 (see Fig. 5 for location), 4 $\mathrm{km}$ southeast of the base of Section PH-B-33. The silcrete is $1.4 \mathrm{~m}$ thick and consists of cryptocrystalline quartz with abundant root traces. The entire rooted zone is $3 \mathrm{~m}$ thick, and it lies at the top of a cross-bedded, smectite-rich sand at the top of the Lebo Member, just below the contact coal bed.

The stratigraphic sections shown in Figure 6 contain five separate, thin, rippled sand units that contain both burrows, indicative of marine influence, and freshwater body fossils. The oldest unit, the basal burrow bed, was mentioned earlier. The other four units contain Skolithos linearis and Teichichnus, and in bed 4 of Section PH-B33 they are also found with the addition of the U-shaped burrow identified as Arenicolites.

The following units are used to correlate all the Tongue River sections throughout the Pine Hills study area (Belt et al., 1992): (1) the E- and F-coal zones; (2) five shell-bearing sandy burrow beds; (3) contact coal zone; and (4) a white bed (possibly with diatoms) above the contact coal zone. The F-coal is also known as the Dominy coal (Matson and Blumer, 1973).

\section{Conclusions Developed from Terry Badlands and Pine Hills} Areas

In both the Terry Badlands and Pine Hills areas, a lowering of base level caused paleovalleys to be cut. These were subsequently backfilled during transgression by sediment of the Tongue River Member. Tongue River coal and marine-influenced beds formed the transgressive and early highstand phases of the upper part of that sequence. These spread out beyond the paleovalley to cover the old interfluve ridges. 


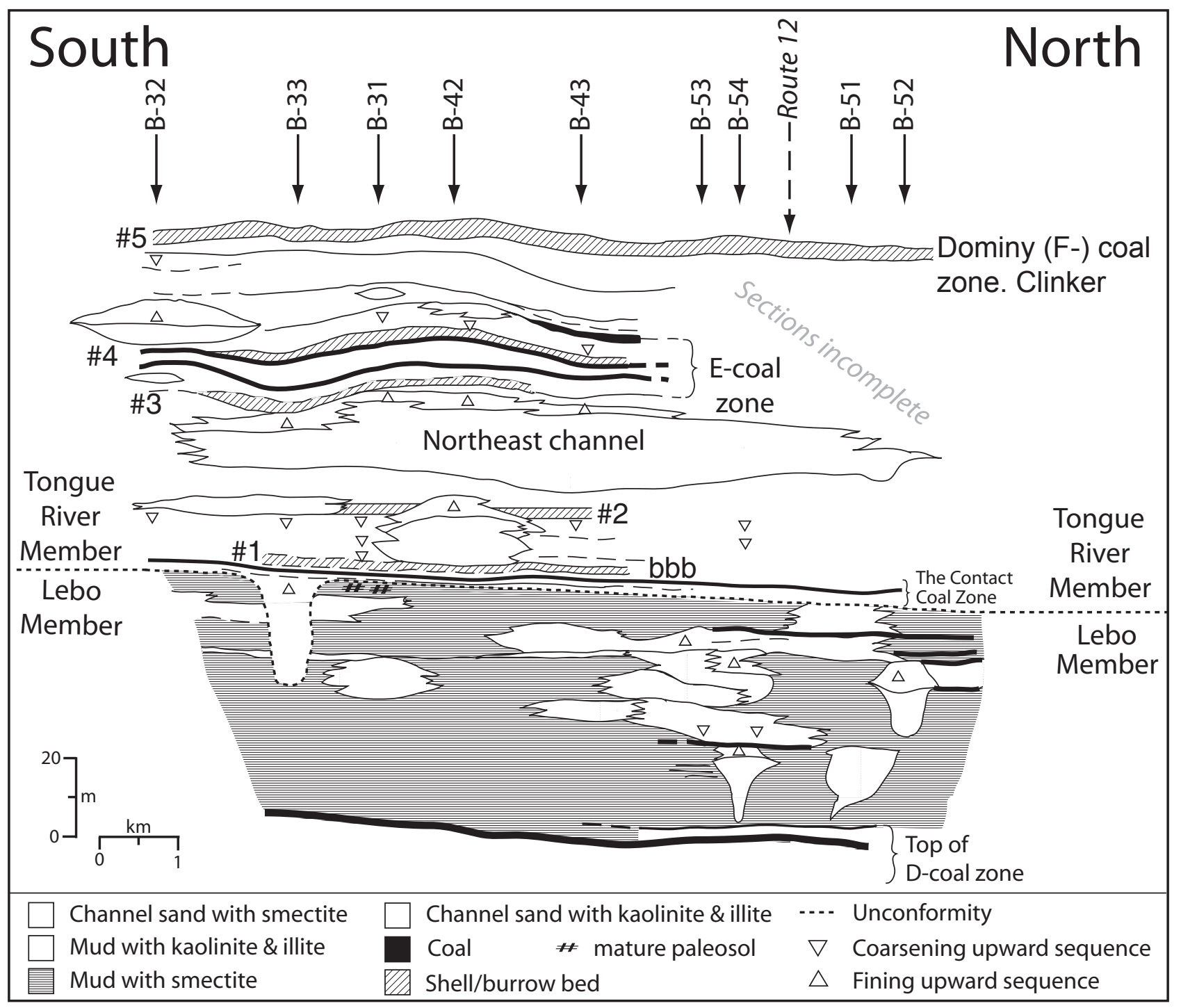

Figure 6. Correlation of nine stratigraphic sections in Pine Hills area (see Fig. 5) based, in part, on unpublished work (Belt et al., 1992). Note occurrence of a paleovalley at base of Tongue River Member in section PH-B-33. Correlation is based on: (1) top of D-coal zone; (2) contact coal zone (Parker and Andrews, 1939); (3) five marine-influenced shell beds; and (4) Dominy (F) coal zone, which includes the fifth shell bed. $b b b=$ basal burrow bed.

Paleovalleys are not common at the Tongue RiverLebo contact, which is typically planar when viewed in cross section (see Belt et al., 1992, fig. 4). Note in Figure 6 that only one paleovalley was found at the Lebo-Tongue River contact in a minimum distance of $8 \mathrm{~km}$ along that contact. Similarly unusual occurrences exist in the areas of the Pine Hills (Fig. 5) and Terry Badlands (Fig. 3).

The paucity of paleovalleys suggests a relatively brief period of erosion during the lowered base level. If that erosion had been more prolonged, then more numerous and deeper paleovalleys would have been produced. The fact that the mature paleosol at the top of the Lebo Member (Fig. 7) does not consistently occur along strike suggests that either paleosols did not develop on every interfluve or that they were eroded away.

When considered from a regional map perspective, the paleovalleys at Pine Hills and Terry Badlands form a definite pattern. The direction of the paleovalley at Pine Hills is north to northeast, that is, towards the Terry Badlands study area. The direction of the paleovalley at TB is toward the south. The paleovalley directions at both localities are based on paleocurrent azimuths from cross 


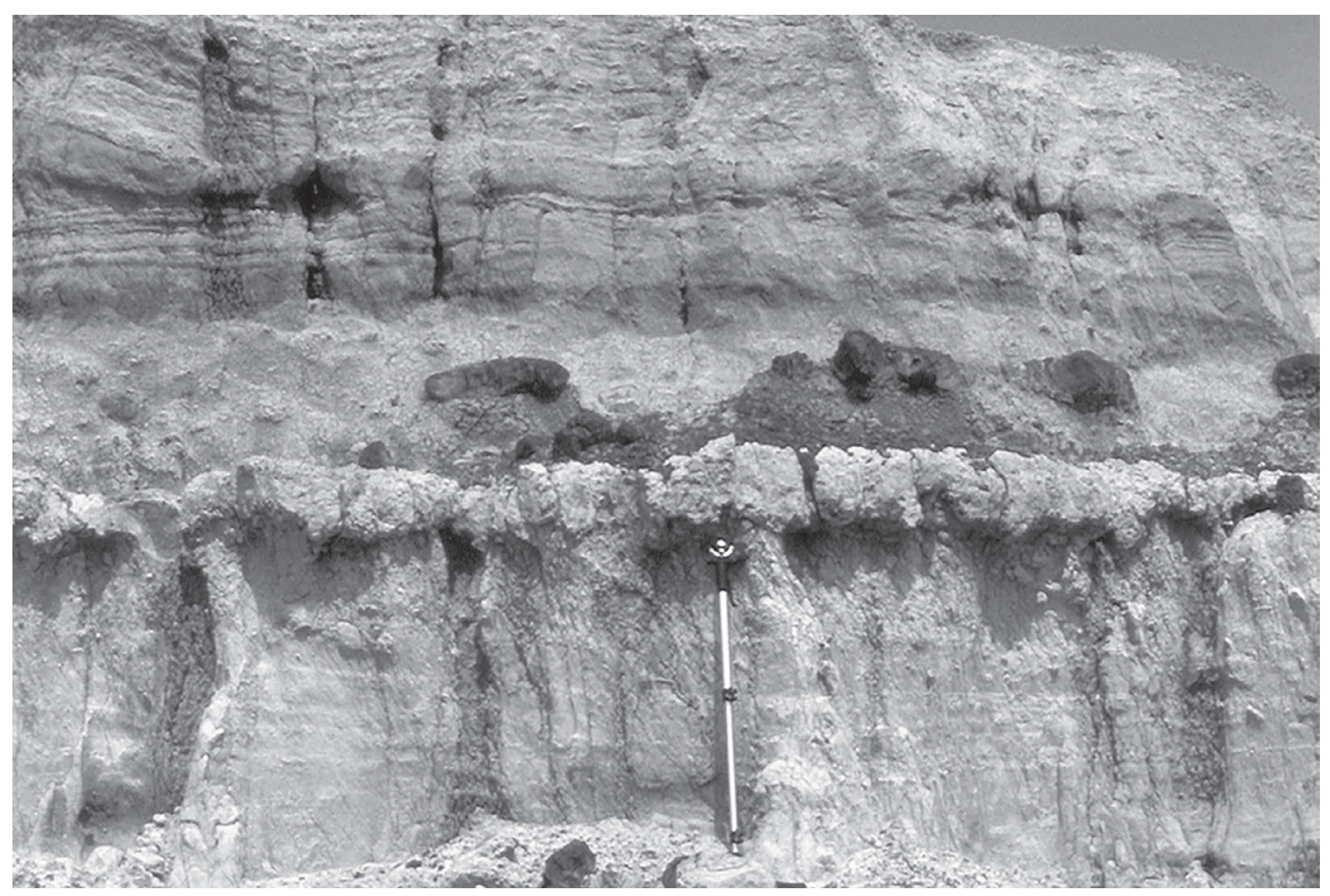

Figure 7. Mature paleosol (1.5 m thick, marked by $1 \mathrm{~m}$-long Jacob staff) at top of Lebo Member, section PH-B-56 (Fig. 5, item 56). Note limited bedding due to partial disruption by root traces. Resistant ledge is a $30 \mathrm{~cm}$-thick bed of silcrete. Belt et al. (1992, fig. 4) show a view looking north at Lebo-Tongue River contact from top of butte that was composed of same silcrete layer shown here.

beds in sand. The convergence of these two trends at the same contact suggests that the paleovalleys in the TB and $\mathrm{PH}$ areas may be coeval tributaries to a common trunk paleovalley that flowed southeast in the area between them, in the direction of the Cannonball Sea.

\section{Signal Butte Area (Locality SB, Figs. 1 and 2)}

Nearly $200 \mathrm{~m}$ of strata are exposed at Signal Butte, near Miles City, Montana (SB, Fig. 1). The Tullock-Lebo contact (Fig. 2) is close to the base of the butte, above which occurs a complete, 118 m-thick section of the Lebo Member. Overlying the Lebo Member, the lower $48 \mathrm{~m}$ of the Tongue River Member is capped by a unit of red clinker that resulted from Holocene burning of coals (Belt et al., 1992). The Dominy (or F-coal) zone above the E-coal zone (Fig. 6) occurs $5 \mathrm{~km}$ east and northeast of Signal Butte at the western edge of the Pine Hills plateau (Matson and Blumer, 1973).
The Tongue River Member is distinguished from the Lebo Member using the same clay-mineral criteria as used in the PH and TB areas. The base of the Tongue River Member consists of a rippled, yellow sand that lies directly above smectite-rich muds and sands of the Lebo Member. The contact coal bed or zone of PH or TB areas apparently is not present there.

The basal burrow bed ("bbb") occurs just above the basal contact of the Tongue River Member. It is a currentrippled, fine-grained, carbonate-lithified sandstone that contains a low diversity of marine-influenced trace fossils, including only Skolithos linearis and Teichichnus. The Monocraterion bed, a burrow assemblage of much higher diversity, occurs $24 \mathrm{~m}$ above the basal burrow bed (Belt et al., submitted).

An unconformity has not been recognized at the Lebo-Tongue River contact at Signal Butte. This is not surprising considering the rarity of paleovalley occurrences 
at the contact in the PH and TB areas. Recent studies by Kirk R. Johnson (Denver Museum of Nature and Science, e-mail, June 29, 2004) indicate a significant megafloral change at the Lebo-Tongue River contact. Hence this contact is termed a 'correlative conformity' that correlates with the unconformable contact at Pine Hills and Terry Badlands.

\section{Correlating Tongue River Strata to Southeast of SB, PH, and TB Areas}

Strata of lower parts of the Tongue River Member are found southeast and east of the $\mathrm{SB}, \mathrm{PH}$, and $\mathrm{TB}$ areas in the Baker 30' x 60' quadrangle (at, and north, of 7-UP, Fig. 1; Vuke et al., 2001). It contains many thin white beds, some including silcrete, but otherwise it consists of lithologic characteristics typical of the Tongue River Member, including the thick, regionally extensive Dominy (or Fcoal) zone. The Dominy coal and associated strata form a clinker that caps a lower interval of the Tongue River Member. This lower interval was tilted to the northwest prior to the deposition of an upper Tongue River unit that lies unconformably above it (Susan Vuke, personal communication, 2004). The younger Tongue River interval is not found in the TB, $\mathrm{PH}$, or $\mathrm{SB}$ areas.

\section{Ludlow-Tongue River Contact East of Cedar Creek Anticline}

Little Missouri River Area (Locality LMR, Figs. 1, 2, 8, 9 , and 10)

The Ludlow Member was initially studied along the north-flowing Little Missouri River (Belt et al., 1984) 20 years ago when about 145 stratigraphic sections were measured. At that time Warwick (1982) had studied the Tongue River Member. The two areas are combined here (Fig. 1) into one large outlined region with a dot indicating our present LMR study area.

Figures 8 and 9 are based on 22 sections, of which 10 are shown. All 22 measured sections are listed in Appendix 1 and located in Figure 10. In Figure 8, the straight-line distance between section LMR-B-102 and section LMR$\mathrm{B}-100$ is $3.2 \mathrm{~km}$. It was constructed in two parts. That is, sections LMR-C-9 and LMR-B-10 form one segment that lies along a line that is subparallel to, but $1.6 \mathrm{~km}$ south of, the other segment (sections LMR-B-102 to LMR-B-12). The two paleovalleys are but the same paleovalley intersected twice.

A complete section of the Ludlow Member is exposed for $35 \mathrm{~km}$ up the Little Missouri River to the south of the sections shown on Figure 8. The Ludlow Member is about 195 m thick (Belt et al., 1984), although the base was not clearly defined by Belt in 1981. Only about $45 \mathrm{~m}$ of the upper Ludlow and $90 \mathrm{~m}$ of the lower Tongue River Members are considered here.

The transition from facies typical of the Ludlow Member into those typical of the Tongue River Member is gradual and forms a $50-\mathrm{m}$ interval that is unique to the Williston Basin. The interval can be subdivided into three mappable units. The first two units belong to the upper Ludlow Member (upper Facies B, Belt et al., 1984) and the third is assigned to lower parts of the Tongue River Member. They are, from oldest to youngest, the: (1) upper Ludlow, meanderbelt facies, starting at $20 \mathrm{~m}$ stratigraphically above the Yule rider coal (Belt et al., 1984, fig. 5, section LMR-B-40, see also Appendix 1); (2) upper Ludlow, Rhame zone; and (3) lower Tongue River, paleovalley and H-coal zone.

\section{Upper Ludlow Meanderbelt Facies}

The upper 35 meters of Ludlow strata directly below the Rhame zone (Fig. 8) form three superimposed meanderbelt deposits (Belt et al., 1984, figs. 5, 16, and 17). They consist of fine- to medium-grained, muddy sand units that are amalgamated to form multistoreyed channel deposits. Sands of thalweg origin are well sorted and show trough cross beds that have an average paleocurrent azimuth to the northeast. Gently dipping units of rippled sand with mud drapes that resulted from lateral accumulation on point bars are coeval with the thalweg sands and overlie them. These lateral accretion deposits, some of which are $8 \mathrm{~m}$ thick, define a discrete storey for each cycle of the superimposed meanderbelt deposits.

\section{Upper Ludlow Rhame Zone Facies}

The Rhame zone consists of light-colored, mud and rippled sand with minor amounts of coal, carbonaceous shale, and silcrete. Roots and rootlets are abundant. Thin, lenticular cross-bedded channel sand deposits are rare.

The color of the mud and sand deposits in the Rhame zone is commonly a brilliant white, but pale purple and pale green colors are also present. Silcrete beds range from a few $\mathrm{cm}$ to $65 \mathrm{~cm}$ thick. The thickness of the Rhame zone varies from less than a meter to about $8.5 \mathrm{~m}$ (Fig. 8). This variation is related to the depth of erosion from the unconformity above it.

The Rhame zone was formerly called the Rhame Bed by Wehrfritz (1978), but it was also known as 'the white marker zone' by Clayton et al. (1977) and Belt et al. (1984). It marks the top of the Ludlow Member through- 
out southeastern Golden Valley County and central Slope and Bowman Counties, North Dakota.

As in the cases of similar strata in Montana (Christiansen, 1984), the Rhame zone has been interpreted as a paleosol (Wehrfritz, 1978). In the LMR area, it developed during the Paleocene by weathering upper units of the Ludlow Member, mostly the meanderbelt facies.

\section{Basal Tongue River Deposits Confined to a Paleovalley}

The oldest strata of the Tongue River Member in the LMR area consist of lenticular, cross-bedded sand units that are incised more than $14 \mathrm{~m}$ into the underlying Rhame zone west of the base of section LMR-B-12 (Fig. 8). Near the top, tabular cross-bedded sand units show rhythmic flow-reversal ripples and mud drapes of possible tidal origin. These sand units are overlain by a thin bed of fine-grained, rippled sandstone containing abundant burrows of Skolithos linearis and Teichichnus. Above this burrow bed, a fining-upward sequence of sand and mud

passes into the black shales and thin coals of the $\mathrm{H}$-coal zone. A very light gray mud bed containing marine diatoms, Coscinodiscus (see Belt et al., submitted), occurs 2 $\mathrm{m}$ above the lowest coal in the H-coal zone (unit \#14 in section LMR-B-100, Appendix 1).

These deposits fulfill all the criteria for a paleovalley and in addition they are confined to a narrow region. The dominant paleoflow direction is to the southwest based on cross beds in the lower, fluvial part of the sand unit, and this is confirmed by the mapped margin of the body that was traced for $2.25 \mathrm{~km}$ (ESB, unpublished data, 1983).

\section{Lower Tongue River H-coal Facies}

The H-coal zone has been reported (Warwick and Luck, 1995) from outcrops only in the region where the Little Missouri River flows eastward around Bullion Butte (Fig. 10). It consists of thin units of dark-gray mud with numerous coal beds less than $0.5 \mathrm{~m}$ thick. Three to five thin coals commonly occur in the zone, but in section

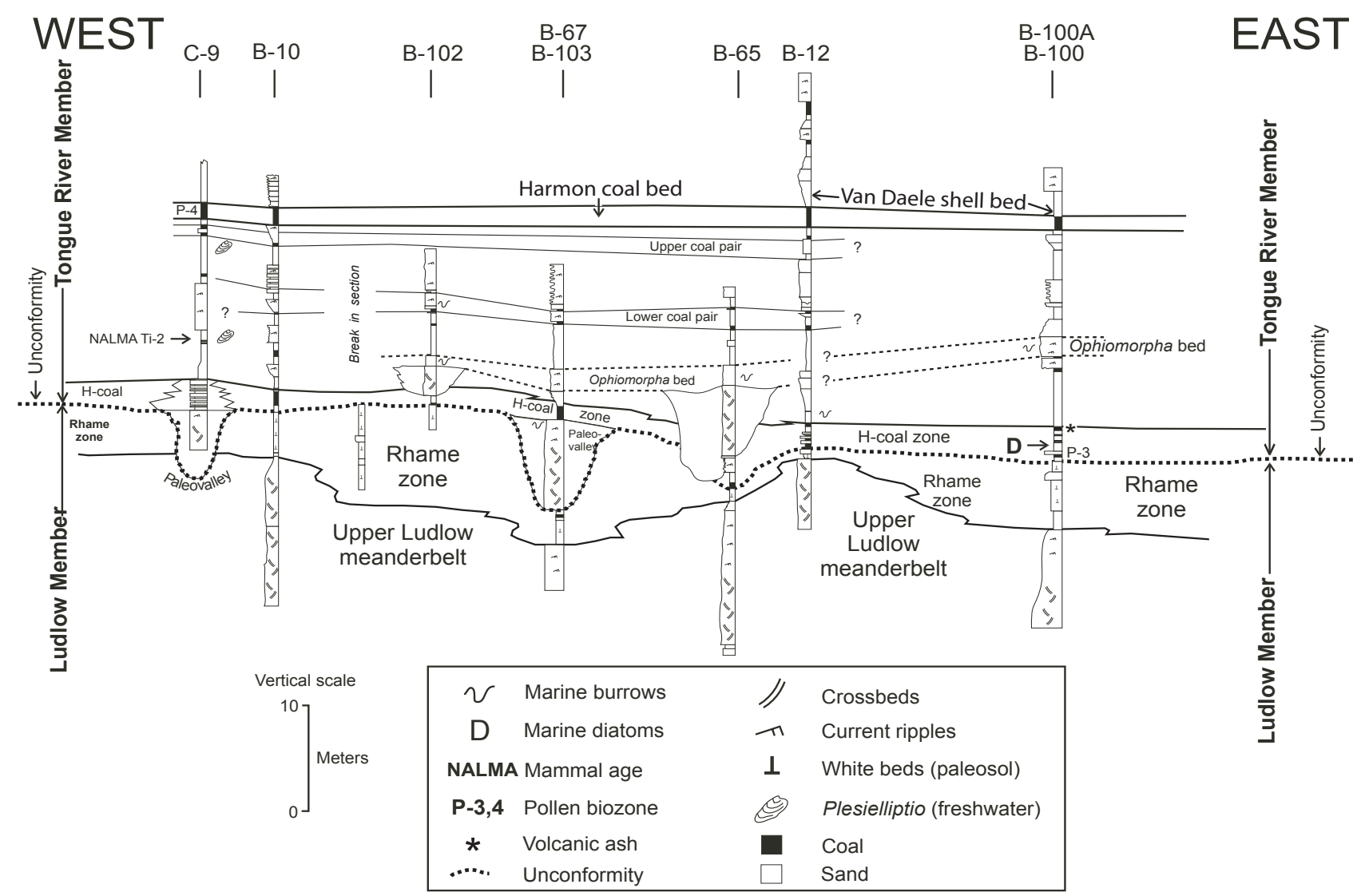

Figure 8. Correlation (see Fig. 10 for locations of sections) of key beds from upper Ludlow and lower Tongue River Members, Little Missouri River field area, western segment. Note on Figure 10 that cross section is divided into two segments at west end. Datum is top of Harmon coal bed. Specific beds show pollen biozones, a NALMA site, and a volcanic ash. Localities 102 and 100 are separated by $3 \mathrm{~km}$. 


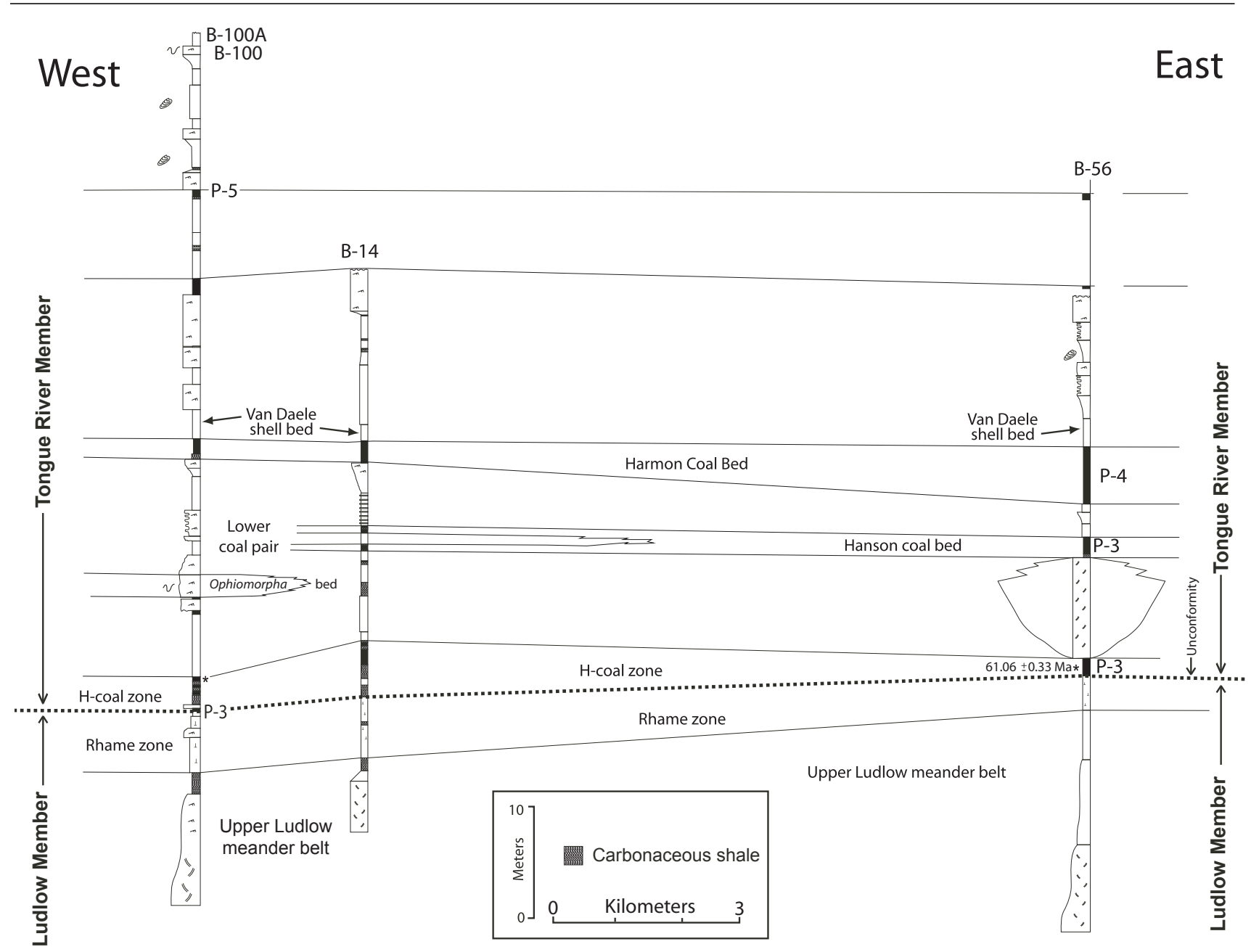

Figure 9. Correlation (see Fig. 10 for locations of sections) of key beds from upper Ludlow and lower Tongue River Members, Little Missouri River field area, eastern segment. Section LMR-B-100/100A forms common link between Figures 8 and 9. Ash bed dated at $61.23 \pm 0.38 \mathrm{Ma}$ (Appendix 3) likely correlates with the one at top of $\mathrm{H}$-coal zone in section LMR-B-100, Figure 8 . Key for most symbols appears on Figure 8.

LMR-B-56 (Fig. 9) the zone consists solely of a $1.5 \mathrm{~m}$ thick coal, which contains a volcanic ash bed that has been dated $61.06 \pm 0.33 \mathrm{Ma}$ (this is the same bed reported as $61.23 \pm 0.38 \mathrm{Ma}$ by Warwick et al., 1995). The top coal in the H-coal zone at section LMR-B-100 also contains a volcanic ash (Fig. 8). Although separated by $14 \mathrm{~km}$ (Fig. 9), these two ash beds are likely the same unit; they both occur in a coal at the top of the $\mathrm{H}$-coal zone. This is the only ash bed found in strata of the Tongue River Member from any of our study areas.

The H-coal zone lies directly above the Rhame zone except where it overlies a paleovalley deposit (Section LMR-C-9, Fig. 8), and it varies in thickness from 0.5 to $2.7 \mathrm{~m}$. This variation depends largely on paleorelief at the time of deposition. The $\mathrm{H}$-coal zone underlies typi- cal lithologies of the Tongue River Member, described below.

\section{Typical Tongue River Facies Above H-coal Zone}

Facies above the $\mathrm{H}$-coal zone consist of typical Tongue River units characterized by light-gray mud and pale-yellow, fine-grained sand dominated by kaolinite and illite. Thin coals are common in the section, but the occasional thicker coal bed, such as the Harmon coal bed or the two unnamed coals above the Harmon (Figs. 8 and 9), can be correlated over vast areas east of the Cedar Creek anticline (Sholes, 1988; Sholes et al., 1989; Flores et al., 1999).

These facies of the Tongue River Member were deposited in a low-gradient coastal setting on the western 


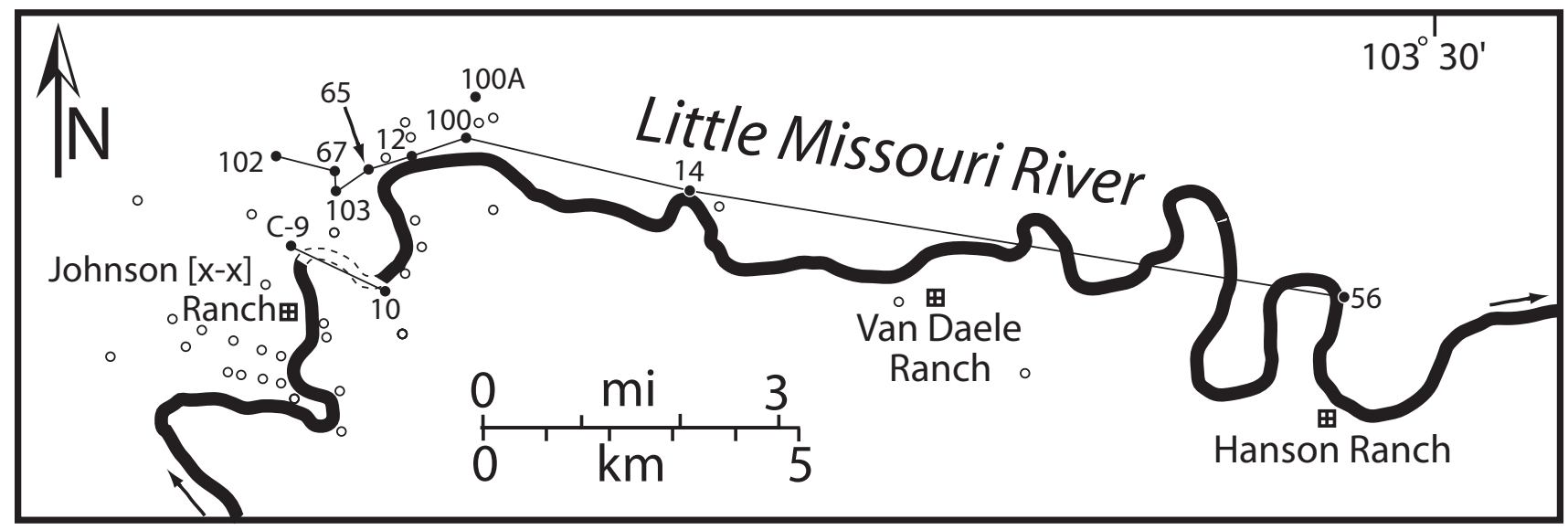

Figure 10. Map showing locations of sections in Figures 8 and 9 in Little Missouri River field area. Specific sites for mammal teeth, radiometric dates, and pollen biozones are located on the X-X, Van Daele, and Hanson Ranches.

margin of the Cannonball Sea. Small distributary channels built thin, prograding delta lobes between which brackish bays formed. The headwaters of the interdistributary bays at times were entirely fresh water. Shortterm salinity fluctuations in these bays were common due to seasonal flooding from the land by fresh water and by storm surge from the sea. In a longer time frame, compactional subsidence and/or changes in the level of the sea also affected the salinity of these interdistributary deposits. The regionally extensive coal beds likely had an allogenic origin of the type described by Belt (1993) for the C-coal zone of Montana.

\section{CORRELATION}

\section{Introduction}

Figure 2 shows the thicknesses of Paleocene members with no absolute time axis. It was deliberately separated on either side of the CCA. Previous charts published by us assumed a time correlation of facies between Montana and North Dakota (Belt et al., 1984, fig. 2; Belt et al., 1992, fig. 2; Belt et al., 1997, fig. 6). Data presented in this section show that to have been a mistaken assumption. Figure 11 is a new correlation chart based on new integrations of pollen biozones, radiometric dates, and the age of mammal sites. Figure 12 emphasizes the probable magnitudes of errors in some of the data used for constructing Figure 11.

\section{Basis for New Correlation Chart}

The ages for pollen biozone boundaries shown in Figure 11 are based on the work of Nichols (1998, 2003). The ages shown for boundaries of the North American Land Mammal Ages (NALMA) are from Hartman and Kihm (1992, 1996), Prothero (1995), Berggren et al. (1995), Hardenbol et al. (1998), and Lund et al. (2002).

The pollen biozones are based on the pioneering work by Nichols (2003 and references cited therein). His published work in the Williston Basin has been concerned mainly with North Dakota. In early phases of our Montana project, and prior to his death (April, 1999), our group relied on Don Engelhardt. Thereafter, we enlisted T. J. Kroeger for assignments of pollen biozonation. During the past year, however, Douglas J. Nichols (USGS, Denver, personal communication, 2004) has checked many of Kroeger's samples and the two palynologists collaborated on many of the pollen biozone designations indicated here. Recently, North Dakota pollen results have become available (Warwick et al., 2004). See Appendix 2 for a list of palynomorphic species found within each of the biozones identified by Kroeger from samples for this report.

The pollen recovered was largely, but not entirely, from coal beds in the Lebo, Ludlow, and Tongue River Members. All volcanic ash beds (va ${ }_{1}$ 3, Fig. 11) but one are from coals in the Lebo and Ludlow Members. The exception $\left(\mathrm{va}_{4}\right)$ is an ash bed from a coal that occurred in the $\mathrm{H}$-coal zone of the Tongue River Member at the Hanson ranch (Fig. 10).

The probable ranges in age of specific mammal sites used hereare shown in Figure 12 (items 8-10). These are reflected as a range, in millions of years, of the entire zone as it appears on Figure 11. See Appendix 3 for details. 


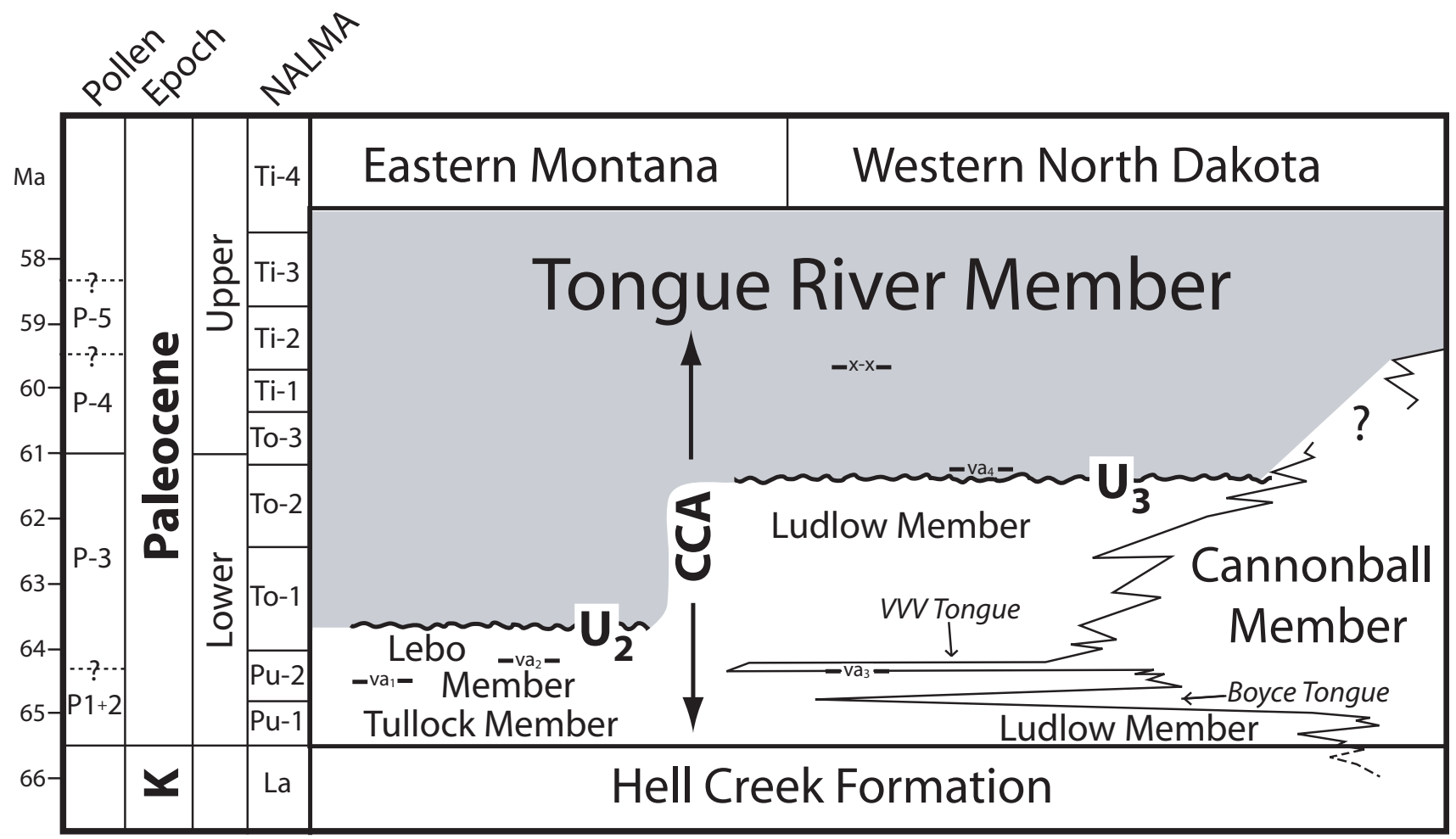

Figure 11. Proposed correlation of members of Fort Union Formation between Signal Butte and Little Missouri River (SB to LMR, Fig. 1). CCA is Cedar Creek anticline (Fig. 1). $U_{2}$ and $U_{3}$ represent unconformities according to nomenclature of Belt et al. (2002). Symbols va ${ }_{1}, \mathrm{va}_{2}, \mathrm{va}_{3}$, and $\mathrm{va}_{4}$ are volcanic ash beds that have been radiometrically dated (Appendix 3). Symbol: X-X is a Ti-2 North American Land Mammal Age (Hunter, 1999).

\section{Results}

\section{Introduction}

The age of the base of the Tongue River Member west of the CCA is considerably older than to the east of the CCA (Fig. 11). In both regions this contact is shown by our data to occur somewhere within the P-3 pollen biozone. The position of the base of the member relative to the top or bottom of that biozone can be estimated, but first the basis of the absolute age assigned to the $\mathrm{P}-2 / \mathrm{P}-3$ and the P-3/P-4 boundaries by Nichols $(1998,2003)$ needs to be examined. The position of pollen biozone boundaries in meters from known lithologic boundaries is indicated from our measured sections. This has not been done previously (e.g., Warwick et al., 2004) and is necessary information for future researchers. The stratigraphic positions of these important pollen biozone boundaries will not change in the sections, but their calculated ages probably will be modified through new radioisotopic work by K. R. Johnson's team.

\section{P-2/P-3 Boundary, Stratigraphic Position, and Radiometric Age}

Nichols (1998, 2003) indicated that the radiometric age for the $\mathrm{P}$ 2/P-3 boundary was "approximately 64.4 Ma” (see va, Fig. 11). This was based on an ash date that came from $1.5 \mathrm{~m}$ above the top of the Oyster coal bed at the Three V Ranch. Table 3 in Warwick et al. (2004) lists pollen biozones for all named coal beds from the Ludlow Member except the Oyster coal bed. Number D8098-F in that table 3 (Warwick et al., 2004) is the correct sample number for the Oyster coal bed (Nichols, USGS, Denver, personal communication, May, 2004). All the coal beds cited in the current literature concerning the Ludlow Member can be unambiguously related to our section LMR-B40 (Belt et al., 1984, fig. 5; see also Appendix 1 for location).

The ash bed $1.5 \mathrm{~m}$ above the Oyster coal bed has a calculated age of $64.4 \pm 1.8 \mathrm{Ma}$ (item 5, Fig. 12). An un-named coal bed occurring $1.5 \mathrm{~m}$ above the Oyster coal is designated P-2 on the basis of palynomorphs. The No. 1 coal bed (Belt et al., 1984), occurring $16 \mathrm{~m}$ above the Oyster coal, has been designated P-3 (sample D8099-D, Warwick et al., 2004, table 3). Thus the P-2/P-3 


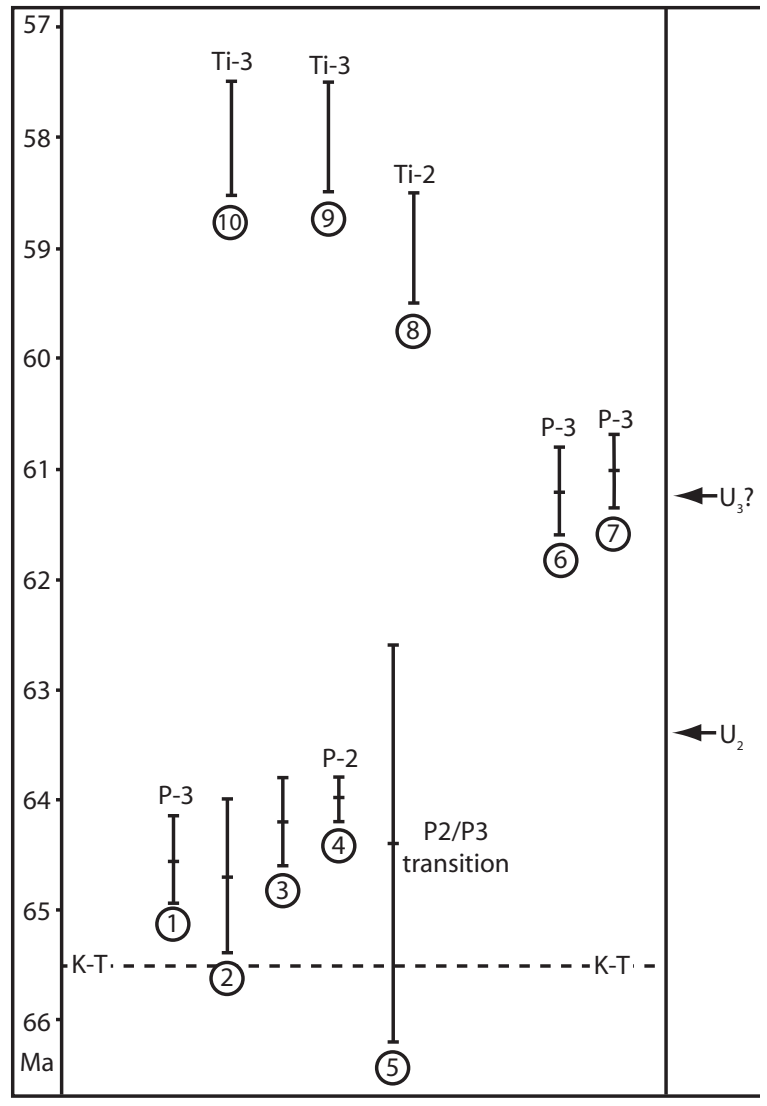

boundary occurs between that unnamed coal and the No. 1 coal bed. The thicknesses between coal units were not included in the report by Warwick et al. (2004). They are from our section LMR-B-40 (Belt et al., 1984, fig. 5) and may differ by a few meters from the unpublished Ludlow section measured by Nichols, Johnson, and Hickey in 1987.

The P-2/P-3 boundary is estimated to occur about $9 \mathrm{~m}$ (our measurement) above the Oyster coal bed. Whatever the radioisotopic age of that boundary ultimately turns out to be, the position of that pollen transition is fixed in the strata. Paleomagnetic work now being done by K. R. Johnson and his team may resolve that difficulty because the estimated experimental error of \pm 1.8 my (item 5 , Fig. 12 ) is unacceptably large. Fortunately, dates from other ash beds (Fig. 12, items 1-4) are useful for narrowing down the ambiguity in the Oyster ash date.

A coal bed in upper parts of the Lebo Member at Signal Butte, $28 \mathrm{~m}$ below the Lebo-Tongue River contact, was assigned to pollen biozone P-3 by D. J. Nichols (personal communication, 2003). The ash in that coal dated at $64.56 \pm 0.43 \mathrm{Ma}$ (item 1, Fig. 12, also va, Fig. 11). However, another ash date occurs at the top of the
Figure 12. Means and standard errors of radioisotopic dates (items 1-7) and probable ranges of Tiffanian mammal sites (items 8-10, based on Fig. 11) discussed in text. Designated pollen biozones of respective coal beds in which ashes occur are also given. $\mathrm{K}-\mathrm{T}$ is Cretaceous-Tertiary boundary. Items 1,2 , and 3 are from Lebo strata west of Cedar Creek anticline (Lehigh Univ. lab; see Appendix 3). Item 4 is from Ludlow strata in Ekalaka area (Belt et al., 2002), and item 5 is from Ludlow strata in Little Missouri River area (Warwick et al., 1995). Items 6 and 7 are from H-coal zone of basal Tongue River Member in Little Missouri River area (see Appendix 3 for further details). Mammal-based item 8 is X-X at LMR area (Hunter, 1999), item 9 is 7-UP site, and item 10 is White Site (see Hartman and Kihm, 1992 for sites 9 and 10). $U_{2}$ and $U_{3}$ are suggested times for development of two major unconformities discussed in text.

Ludlow Member just below the contact with the Ekalaka Member (E, Fig. 1; item 4, Fig. 12; Belt et al., 2002). This ash was dated as $64.03 \pm 0.19 \mathrm{Ma}$ by Vuke and Belt (1995) and was assigned to pollen biozone P-2 by D. J. Nichols (as reported in Belt et al., 2002). The basal coal of the Ekalaka Member (Belt et al., 2002) a few meters above this ash bed was assigned to the $\mathrm{P}-3$ pollen biozone by Nichols (reported in Belt et al., 2002). The disparity between pollen biozones and ash dates more probably resulted from the standards used at the two different laboratories (see Appendix 3) than from pollen misidentification.

Although the isotopic and pollen data from Signal Butte and Ekalaka do not collate well, taken together they indicate that the P2/P3 boundary lies between 63.8 and 64.9 Ma. The section at Signal Butte is being studied by K. R. Johnson's team to establish the isotopic age of the P2/P-3 boundary. Until their results are in, Nichols' (1998, 2003) pick for the P-2/P-3 boundary (64.4 Ma) is used here as a reasonable working hypothesis. Thus the P-2/P-3 boundary in the $\mathrm{SB}, \mathrm{PH}$, and $\mathrm{TB}$ areas occurs close to, but below, the base of the Tongue River Member.

In the Terry Butte area, two volcanic ash beds from upper parts of the Lebo Member (items 2 and 3, Fig. 12; $\mathrm{va}_{2}$, Fig. 11) were sampled from the same coal bed in the D-coal zone; pollen results from these beds were ambiguous.

\section{P-3/P-4 Boundary, Stratigraphic Position, and Radiometric} Age

The P-3/P-4 pollen biozone boundary has been identified only in stratigraphic sections on the Hanson Ranch (Fig. 10). The stratigraphic position of this boundary is easily estimated because table 3 from Warwick et 
al. (2004) shows that it occurs between the Hanson and the Harmon coal beds. Although their publication does not indicate thicknesses of strata, our section LMR-B-56 (Fig. 9) shows that a 3 m-thick unit of root-bearing silt occurs between the top of the Hanson coal bed and the base of the Harmon coal bed (see Appendix 1 for location). Thus, according to Figures 8 and 9, the P-3/P-4 biozone boundary would occur about $12 \mathrm{~m}$ above the volcanic ash that was dated at $61.06 \pm 0.33 \mathrm{Ma}$ (item 7 , Fig. 12). That position means that the P-3/P-4 boundary must be slightly younger than the $61.0 \mathrm{Ma}$ age indicated by Nichols $(1998,2003)$. Nevertheless, Nichols' 61.0 Ma age of the P-3/P-4 boundary is accepted here as a working hypothesis. Thus the unconformity at the base of the Tongue River Member east of the CCA lies near the top of the P-3 pollen biozone.

\section{P-4/P-5 Boundary, Stratigraphic Position, and Radiometric Age}

Nichols (1998, 2003, and personal communication, 2004) indicates that the Harmon coal bed at the Hanson Ranch (Fig. 10) is represented by pollen biozone P-4 (see section LMR-B-56, Fig. 9). Nichols (personal communication, 2004) also kindly supplied us with the stratigraphic positions and biozone designations of two unnamed coal beds above the Harmon; these are shown on Figure 9, section LMR-B-56. The lower unnamed coal bed (P-4) occurs $16 \mathrm{~m}$ above the Harmon coal bed. The upper, unnamed coal bed (biozone P-5) is thicker and occurs ca. 24 $\mathrm{m}$ above the Harmon coal bed. Thus the P-4/P-5 biozone boundary must lie within the intervening $8 \mathrm{~m}$ of strata.

In summary, it is clear that the pollen biozones originally defined by Nichols (2003, and references cited therein) show a sequential ascending order in the strata that extend across a $16 \mathrm{~km}$ east-west segment of Ludlow and Tongue River strata in the Little Missouri River area (Figs. 8 and 9). Note that the entire thickness of the P-4 pollen biozone is present in section LMR-B-56 (and the extension of that section upwards into section Wa-96 of Warwick and Luck, 1995). Biozone P-4 occupies only 26 $\mathrm{m}$ of section, within which there is no obvious unconformity. Biozone P-4 on Figure 11 represents about one million years of geologic history. A $26 \mathrm{~m} / \mathrm{my}$ rate of deposition is very slow and suggests to us that the $60 \mathrm{Ma}$ date given the P-4/P-5 boundary needs to be revised.

Tiffanian-2 Mammal Site and an Older Torrejonian-1 Site

Problems arise when considering the consequences of plotting pollen, mammalian ages, and ash dates on Figure
11. The Ti-2 mammalian age at the X-X site (X-X, Fig. 11) is enigmatic in light of its stratigraphic position. First, and most importantly, the Ti-2 mammal site lies between 6 and $10 \mathrm{~m}$ above the $61.06 \mathrm{Ma}$ ash bed (item 7, Fig. 12) in the $\mathrm{H}$-coal zone. Second, the X-X site occurs $11 \mathrm{~m}$ below the Harmon coal bed (section LMR-C-9, Fig. 8), which was assigned to the $\mathrm{P}-4$ pollen biozone (Nichols, personal communication, 2004). Third, the next coal below the Harmon is the Hanson coal, which had been assigned to a P-3 pollen biozone (Nichols in Warwick et al., 2004, table 3). Our correlation in the $16 \mathrm{~km}$ interval between the two sections (compare Figs. 8 and 9) shows that the Ti-2 mammal site at the X-X occurs in the P-3 pollen zone. Fourth, the stratigraphic position of the Ti-2 mammal site would place it below the lower coal pair (Fig. 8), which, as noted earlier, correlates with the P-3 Hanson coal bed.

The stratigraphic position of the X-X mammal site is properly placed. It is not the result of faulty lithological or biozonal correlation. The lithologic correlation (Figs. 8 and 9) is based on key lithological marker beds, traceable for $16 \mathrm{~km}$ in nearly continuous outcrop from west to east. These lithological marker beds are, from the top down, the upper unnamed coal bed (palynozone P-5), the lower unnamed coal bed (palynozone P-4), the Van Daele shell bed (containing an unusual bivalve, Pachydon), the Harmon coal bed (palynozone P-4), the upper coal pair that passes eastward into the Hanson coal bed (palynozone P-3), the lower coal pair, Ophiomorpha bed, the $\mathrm{H}$-coal zone (palynozone P-3), a volcanic ash bed (61.06 $\mathrm{Ma}$ ) in the top $\mathrm{H}$-coal bed, the Rhame zone, and the upper Ludlow meander belt. The biozones are also ordered in a logical progression.

If lithological correlation was not the problem, could it be the result of the age assignmment given the mammal teeth at the X-X site? That evaluation, given by Hunter (1999, table 3), was based on only one species. He noted the presence of Plesiadapsis anceps, which is a species elsewhere confined to the Ti-2. Associated species are Palaeotomus cf. P. senior and Ectocion collinus, both of which range from Ti-1 through Ti-2, and Ptilodus sp. C, which ranges from $\mathrm{Ti}-2$ through Ti-3. The mammalian age of the assemblage thus clusters around Ti-2 (John Hunter, personal communication, 2002). As mentioned, the coals below the Harmon coal bed (Hanson and H-coal beds) have been assigned to the P-3 biozone by Nichols (in Warwick et al., 2004, table 3), and the $\mathrm{H}$-coal bed contains a $61.06 \mathrm{Ma}$ volcanic ash date. The expected mammal age would be To-3 according to Figure 11. 
Another discrepancy between a NALMA site and the pollen biozones can be documented from the lower Ludlow Member, ca. $85 \mathrm{~m}$ above the K-T boundary (Belt et al., 1984, fig. 5). This site is the younger of the two Brown Ranch mammal sites, and it occurs stratigraphically just above the Boyce Tongue (Fig. 2) or about $4.5 \mathrm{~m}$ above the T-Cross coal bed (Appendix 1; Belt et al., 1984, their channel 4, fig. 6). The NALMA reported by Hunter (1999, table 2) is To-1 to To-2. The T-Cross coal has been assigned by Nichols to pollen biozone P-2 (Warwick et al., 2004, table 3). Even though the older of the two ages was assumed, there is still a discrepancy between the NALMA and the pollen ages. A Puercan age would be expected from mammal teeth associated with a P-2 pollen biozone (Fig. 11).

The dating discrepancy between the pollen biozone and mammalian ages cannot be resolved here. Mammal ages and pollen biozones have been applied widely in the western Williston Basin, and it is reasonable to assume that the estimated ages derived from each set are internally consistent, even though the two sets may not be perfectly collated in absolute time. Given this assumption, available data are used here for making a synthesis of regional tectonic and depositional events. The assumption is reasonable, because the record is subdivided by unconformities.

\section{DISCUSSION}

\section{Introduction}

One unconformity at Pine Hills and Terry Badlands west of the Cedar Creek anticline $\left(\mathrm{U}_{2}\right.$, Fig. 11) and the other unconformity at the Little Missouri River east of the CCA $\left(\mathrm{U}_{3}\right.$, Fig. 11) differ in age by more than two million years. This difference is estimated on the basis of the amount of strata in the Tongue River Member found above those unconformities in the two areas. Once pollen biozones had been assigned to the strata, it becomes clear that $>85 \mathrm{~m}$ of strata of the Tongue River Member bearing palynomorphs characteristic of biozone P-3 occur above the $\mathrm{U}_{2}$ unconformity west of the CCA. In contrast, ca. $70 \mathrm{~m}$ of strata of the Ludlow Member bearing biozone P3 occur below the $\mathrm{U}_{3}$ unconformity at LMR, east of the CCA. At LMR, only $15 \mathrm{~m}$ of strata bearing pollen characteristic of biozone $\mathrm{P}-3$ occur above the $\mathrm{U}_{3}$ unconformity.

It is then worth exploring whether one or both of these unconformities extend beyond the regions of their discovery (Fig. 11). If the younger unconformity from the LMR area were to be extrapolated west of the
CCA, would it occur in the middle of the Tongue River Member in that region? Next, if the older unconformity were to be extrapolated east of the CCA, would it then occur in the middle of Ludlow Member in the LMR area?

\section{Tracking the Younger Unconformity West of CCA}

The Baker quadrangle is situated east of the Pine Hills area (PH, Fig. 1), far south of the Terry Badlands area (TB, Fig. 1); it overlaps the northern edge of the Ekalaka area (E, Fig. 1; Belt et al., 2002). Within that 30' x 60' quadrangle, Vuke et al. (2001) mapped an angular unconformity that separates the Tongue River Member into older and younger units. The older unit dips gently to the northwest, and the younger unit lies horizontally above it.

The older Tongue River unit in the Baker quadrangle is estimated to occur stratigraphically in the middle of the Tongue River succession. The precise thickness cannot be determined at this time. The strata in this interval consist of units of numerous thin, bleached beds, some with silcrete. These are interbedded with stratigraphic units typical of the Tongue River Member. Vuke et al. (2001) refer to this lower part of the Tongue River Member as the 'paleosol interval.' Although some of the white beds may eventually be shown to contain marine diatoms, those with silcrete are clearly paleosols.

White beds and silcrete units occur in lower parts of the Tongue River Member both at Signal Butte and at Terry Badlands (Vuke and Colton, 2003). The Dominy coal zone, a unit that typically is fused sediment and burned-out coal, has been correlated into the Pine Hills area (top of section, bed 5, Fig. 6) and to the west $10 \mathrm{~km}$ east of Miles City, near Signal Butte. Silcrete was found $40 \mathrm{~m}$ above the base of the Tongue River section at Signal Butte. Thus Vuke's 'paleosol interval' of the Baker quadrangle can be correlated to strata in lower parts of the Tongue River Member in the SB, PH, and TB areas.

We refer to the part of the Tongue River Member lying below the unconformity in the Baker quadrangle as the "Dominy" interval because the Dominy coal zone from the Pine Hills area probably correlates with these strata (Vuke, Montana Bureau of Mines and Geology, personal communication, 2004). The younger unit of the Tongue River Member in the Baker quadrangle has lithologic characteristics typical of the Tongue River Member without white beds or silcrete. The dominant coal in the upper part of the Tongue River Member in the Baker quadrangle correlates with the Knobloch coal zone as seen southwest of the Powder River (Sholes, 1988). Thus the 
younger part of the Tongue River Member is referred to as the "Knobloch" unit.

The Ekalaka research area (Belt et al., 2002, fig. 4) extends across the northern margin of the Ekalaka 30' x 60' quadrangle (Vuke et al., 2001) into the southern part of the Baker quadrangle. The "Knobloch" unit of the Tongue River Member is present in the Ekalaka area at the White Site mammal locality, which occurs $1.75 \mathrm{~km}$ north of the Medicine Rocks State Park boundary (Belt et al., 2002, fig. 4). Between this mammalian site and the park, the "Knobloch" unit rests unconformably on the Ekalaka Member (Belt et al., 2002, fig. 5). The Ekalaka Member is a newly named member of the Fort Union Formation. It was formerly mapped as Tongue River Member (Bergantino, 1980).

The bed containing mammal teeth at White Site (Krause, 1987; Strait and Krause, 1988) occurs 40 m above the unconformity. David W. Krause (personal communication, 1998) insists that the teeth at the White site are not Ti-2 in age, but "younger than Ti-2." Hence, item 10 in Figure 12 is plotted in subzone Ti-3. The unconformity, ca. $40 \mathrm{~m}$ below the mammal teeth at the White Site, was called the $\mathrm{U}_{3}$ unconformity in the Ekalaka area (Belt et al., 2002).

Mammalian teeth occur in the "Knobloch" unit at 7-UP Butte, $13 \mathrm{~km}$ NNW of the White Site, (7-UP, Fig. 1 ; item 9, Fig. 12). These are assigned to Ti-3 (see references in Hartman and Kihm, 1992, 1996; Lund et al., 2002). Here, the mammal-bearing site is ca. $80 \mathrm{~m}$ above the unconformity. The Highway Blowout mammal site, roughly between the 7-UP site and the White Site, also has a North American Land Mammal Age of Ti-3 (Hartman and Kihm, 1992). It, too, occurs in the "Knobloch" unit, although the distance above the unconformity can only be approximated.

In summary, in Montana the mammal-based age of "Knobloch" strata above the unconformity is Ti-3 (White Site, 7-Up site, and Highway Blowout site). The oldest stratum just above the unconformity is slightly older than the age of the mammal sites because the mammalian tooth horizons are ca. 40 to $80 \mathrm{~m}$ above the unconformity. It is thus a reasonable assumption that the unconformity $<10 \mathrm{~m}$ below the Ti-2 mammal site at the X-X Ranch in North Dakota would correlate with the sub-"Knobloch" unconformity at the 7-UP and White sites. Note that the "Knobloch" unit of Tongue River Member shows consistent Tiffanian ages and lies above the unconformity, which we identify as the $\mathrm{U}_{3}$.

\section{The Older Unconformity West of CCA}

The existence of the older unconformity at the base of the Tongue River Member in the $\mathrm{PH}, \mathrm{TB}$, and $\mathrm{E}$ areas west of the CCA is based on the change in clay minerals and on prominent Tongue River paleovalleys that were incised into the mature paleosols of the Lebo Member. The age of this unconformity is partly constrained from below by radiometric dates from Lebo Member, as shown on Figure 12 (items 1-4). The unconformity lies near the base of the P-3 pollen biozone (Appendix 2). Note that in the SB area, the Lebo-Tongue River contact is not an unconformity. Rather, it is a 'correlative conformity' that is marked by a significant megafloral change at the boundary (Kirk R. Johnson, Denver Museum of Nature and Science, personal communication, June, 2004).

In the Ekalaka area, the older unconformity was called the $\mathrm{U}_{2}$. It resulted from erosion that removed the entire Ludlow Member and the upper third of the Hell Creek Formation south of the town of Ekalaka (Belt et al., 2002). To the north, the amount of strata missing from the Ludlow Member by way of this unconformity decreases. This unconformity was thus considered to have resulted from erosion following upwarping along the Miles City arch, accompanied by uplift of the Black Hills. The age of the unconformity is constrained below by an ash date of 64.0 Ma that was taken from a coal bed bearing palynomorphs characteristic of biozone P-2 (Fig. 12, item 4). The oldest strata deposited above the $\mathrm{U}_{2}$ were assigned to biozone P-3 (pollen data from Nichols, related to Vuke and cited in Belt et al., 2002).

\section{An Older Unconformity East of CCA?}

Although the $\mathrm{U}_{2}$ unconformity has an obvious tectonic signature west of the CCA, that same tectonic event can be recorded east of the CCA from unique facies within Ludlow strata along the Little Missouri River. These facies, best seen at the top of section LMR-B-40 (Belt et al., 1984, fig. 5), are meanderbelt facies in upper parts of the Ludlow Member. They are also shown at the bases of the sections presented in Figures 8 and 9. Three separate meanderbelts were recognized, and they all have a northeasterly trend. The oldest is channelbelt 10 of Belt et al. (1984, fig. 5); a paleogeographic map of it appears in their figure 16. The two youngest meanderbelts are shown by Belt et al. (1984) in their figure 17.

Twenty-two years ago, strata on the LMR were not studied by Belt with the view of finding an unconformity 
within the upper Ludlow Member. Thus the existence of paleovalleys, and hence an unconformity, cannot be determined using the information currently at hand. However, the sudden change from facies typical of the Ludlow Member to a unique facies in Ludlow, consisting of a 35 m-thick succession of amalgamated meanderbelts - at approximately the right "time" for the $\mathrm{U}_{2}$ unconformity - is not simply a matter of coincidence. An uplift of the Black Hills probably caused the great outpouring of such sediment.

\section{TECTONIC AND DEPOSITIONAL SUMMARY}

\section{Introduction}

The Miles City arch (MCA) and the Cedar Creek anticline (CCA) are two narrow tectonic structures that bring Cretaceous strata to the surface and interrupt the continuity of otherwise flat-lying Paleocene strata in eastern Montana. The SB, PH, TB, and E study areas occur between these two anticlinal structures. Geologists have long been tantalized by the possibility of syndepositional tectonic activity related to one or both of them (Clement, 1986; Winczewski and Groenewold, 1982).

\section{Sequence of Events}

From the time of deposition of Hell Creek facies (latest Cretaceous) through the deposition of the Tullock and lower Ludlow facies (early to mid Paleocene), smectite-rich sediment was deposited in the western Williston Basin. Paleodrainages during all this time flowed to the southeast toward the site of the present Black Hills (Belt, 1993; Belt et al., 1992, 1997, 2002). This suggests that, prior to the $\mathrm{U}_{2}$ unconformity, the Black Hills had no discernible topographic relief.

The direction of paleodrainage changed during the early Torrejonian, when the $\mathrm{U}_{2}$ unconformity was produced. After this time, paleodrainages show a consistent northeasterly trend over a wide area. The change in drainage direction resulted from upwarping of the MCA-Black Hills axis (Vuke and Belt, 1995). After the period of upwarping, normal sedimentation typical of the Tongue River Member occurred above the $\mathrm{U}_{2}$ in the $\mathrm{SB}, \mathrm{PH}$, and TB areas. In the Ekalaka area (Fig. 1), a sandy version of Tongue River facies, the Ekalaka Member, was deposited at that time.

East of the CCA, smectite-rich strata of the Ludlow Member were deposited during most of Torrejonian time. The shift in paleodrainages from southeasterly to northeasterly courses is recorded in Ludlow facies at about 40 $\mathrm{m}$ above the Oyster coal bed at the base of the Three $\mathrm{V}$ Tongue (Figs. $2 B$ and 11).

Strata of Torrejonian age show markedly different facies on either side of the CCA. Figure 11 shows that east of the CCA, smectite-rich strata belong to the upper Ludlow Member and west of the CCA, strata of the same age belong to the smectite-poor, lower parts of the Tongue River Member. This difference in clay-mineral dominance might have resulted simply by an interfingering of the two facies from west to east across the position of the present CCA (i.e., the evidence has been eroded away). However, smectite-poor strata are interpreted to have been better drained than the smectite-rich strata. This would require an impediment due to the CCA between the two areas. Upwarping of at least the northern part of the CCA could have caused such a blockage, and the western Williston Basin would have been partitioned.

The two marine tongues of the Cannonball Member (Three V and Boyce) consist of some organic-rich, muddy sediment (when they contain the oyster reefs of the Three $\mathrm{V})$, but these tongues are characterized by yellow sand. The local river channels, on the other hand, contain abundant smectite. These sands are low in smectite, which suggests a geochemical change from river-borne smectite to kaolinite and illite clay minerals that were deposited on crevasse splays and marine incursion deposits. That change resulted from the presence of marine waters.

Finally, uplift of the Black Hills to the south of the Williston Basin would have exposed to weathering and erosion the volcanogenic, Upper Cretaceous Pierre Shale. Hence, weathering of that, and similar formations, would have shed smectitic clays into the depositional basin. We do not know if there were northerly sources of smectite from the Canadian side of the basin, which otherwise produced mostly kaolinitic and illitic clay minerals.

The northwest tilting of the "Dominy" unit of the Tongue River Member resulted from an uplift of the Black Hills and led to development of the $\mathrm{U}_{3}$ unconformity. This uplift occurred during the late Torrejonian. There was no known tectonic movement specific to the Cedar Creek anticline at that time.

Deposition during the Tiffanian followed the $\mathrm{U}_{3}$ unconformity. The "Knobloch" unit of Tongue River lithofacies includes many widespread coal beds and coal zones. These have been correlated, albeit tentatively, across the Cedar Creek anticline (Sholes et al., 1989) from North Dakota to the region between the CCA and the MCA. The regional uplift of the Black Hills that led to the 
middle Tongue River unconformity was the final tectonic event during the Paleocene.

\section{CONCLUSIONS}

Strata of the Tongue River Member can be distinguished from those of the older Lebo and Ludlow Members by lithological and sedimentological changes; the most noticeable are the differences in dominance of clay minerals. Incised valley fill (paleovalley) deposits are recognized at the Lebo-Tongue River contact in the Terry Badlands (TB), Pine Hills (PH) study areas, and at the Ludlow-Tongue River contact in Little Missouri River (LMR) study area. The sequence of lithologic characteristics observed within the paleovalley indicates a change in base level (relative level of the Cannonball Sea) from regression (that caused incision) to transgression (that caused back-filling) and ultimately to highstand marine and brackish flooding over previous interfluves. Those interfluves had developed a mature paleosol during the time of lowstand. The contact between the Tongue River Member and older strata is thus an unconformity in the western Williston Basin.

A new correlation chart (Fig. 11) was constructed that integrates standard pollen biozones (Nichols, 2003) and the North American Land Mammal Ages (NALMAs) with a radiometric time scale. Bio- and chronostratigraphic dates from our samples of pollen and volcanic ash were integrated with previously published ages from samples of pollen, volcanic ash, and several sites bearing fossil mammals. The results showed that the two unconformities differ in age on either side of the CCA.

Results also show that there is a disparity in absolute ages between pollen biozones and the North American Land Mammal Ages (NALMAs). The best example of this problem comes from the LMR study area. A volcanic ash bed from the $\mathrm{H}$-coal zone at the Hanson Ranch is dated at $61.06 \pm 0.33 \mathrm{Ma}$ and was assigned to pollen biozone P-3. This ash bed from a coal bed bearing palynomorphs characteristic of biozone P-3 occurs stratigraphically between 6 and $10 \mathrm{~m}$ below the X-X mammal-bearing site dated as Ti-2 (Hunter, 1999). The stratigraphic section in this area shows no sedimentological or lithological evidence for an unconformity between the level of the volcanic ash bed and that of the X-X mammal-bearing bed (Figs. 8 and 9).
The following stratigraphic conclusions can now be made. West of the Cedar Creek anticline (CCA), the base of the Tongue River Member is more than two million years older than east of the CCA. There, the older unconformity occurs nearly at the base of the P-3 pollen biozone, and east of the CCA the younger unconformity lies nearly at the top of the P-3 pollen biozone. There are $85 \mathrm{~m}$ of strata dated as biozone P-3 in the Tongue River Member west of the CCA, whereas there are $77 \mathrm{~m}$ of strata of the Ludlow Member east of the CCA palynomorphically dated as P-3 (compare Figs. 2 and 11). Hence the lower 85 $m$ of strata of the Tongue River Member west of the CCA are coeval with $77 \mathrm{~m}$ of strata in upper parts of the Ludlow Member east of the CCA.

The older unconformity had been identified in the Ekalaka study area as $U_{2}$ (Belt et al., 2002). This term is now extended into the $\mathrm{PH}$ and $\mathrm{TB}$ study areas, and on the basis of sedimentological and lithological changes in the appropriate part of the section, the $\mathrm{U}_{2}$ is represented by a correlative conformity in the SB and LMR areas.

A younger unconformity (the $\mathrm{U}_{3}$ ), in and north of the Ekalaka area, is overlain by strata dated as Ti-3 on the basis of fossil mammals. This unconformity is recognized within the Tongue River Member (Baker quadrangle, Vuke et al., 2001), and it separates a tectonically tilted older "Dominy" unit from a younger, flat-lying "Knobloch" unit west of the CCA. This is probably the same unconformity found between the Tongue River and Ludlow Members in the LMR area, although the mammal-based date just above it is Ti-2 rather than the usual Ti-3 as found west of the CCA.

The above results allow us to suggest the following geological evolution of the western Williston Basin. During early and mid Torrejonian time, the CCA was a low barrier that partitioned the western Williston Basin. The barrier segregated smectite-rich deposits of the Ludlow Member from kaolinite- and illite-rich deposits of the Tongue River Member. This could have been accomplished either by upwarping of the CCA or nonsubsidence of the CCA region as the regions on either side subsided. During earliest Torrejonian time, the Miles City arch and the Black Hills were uplifted and eroded to produce the $\mathrm{U}_{2}$ unconformity west of the CCA along with the meanderbelt facies characteristic of upper parts of the Ludlow Member in the LMR east of the CCA. During late Torrejonian and early Tiffanian time, the Black Hills was further uplifted and eroded to produce the $\mathrm{U}_{3}$ unconformity. This tilted strata in lower parts of the Tongue River Member ("Dominy" unit) to the northwest. 


\section{ACKNOWLEDGMENTS}

The authors greatly appreciate the following sources of funds for this project: Faculty Research Award (Belt); U.S. Department of Energy; National Geographic Society; National Coal Resources Data System of the U.S. Geological Survey; North Dakota EPSCoR Research Opportunity Program (Hartman); Faculty Development Grant (Diemer); CFCD Grant Smith College (Tibert); and Geology and Earth Science Discretionary Account (Kroeger).

The authors thank the following for their thoughtful, critical analysis of various versions of this report: Robert G. Raynolds and Donald L. Lofgren (reviewers), Jason A. Lillegraven (RMG), Kirk R. Johnson (Denver Museum), Douglas J. Nichols (USGS, Denver), and Susan M. Vuke (MBMG). James W. Hagadorn drafted Figures 2, 5-6, and 9-12; Emily H. Belt drafted Figure 1.

Research projects by the following undergraduates added measurably to our understanding of the complexities of this geology: Russ Abell, Barret Cole, Kevin Conway, Kirk R. Johnson, Barnaby Rockwell, Susan E. (Hubbard) Sakimoto, Valerie Tamm, Bob Waskowitz, and Bonnie Wong.

Access over the past 22 years was kindly granted by the following ranchers: Don Hartmann, Bill Johnson, Gary Van Daele, John Hanson, Charles Weinreis, Bill Boulware, Nora Bradshaw, and Dr. Donald Beumer.

This report is dedicated to: Susan M. Vuke, for the 15 years of lengthy phone conversations and for visiting our outcrops, for sending us numerous sketches and maps, for constructive and always wise criticism, and at the heart of it all for adding her horizontal mapping perspective to our vertical cross section perspective; and to Douglas J. Nichols, for being a seeker of truth under difficult circumstances, no matter where the chips may have fallen.

\section{REFERENCES CITED}

Belt, E. S., 1993, Tectonically induced clastic diversion and the origin of thick, widespread coal beds, Appalachian and Williston Basins, U. S. A., in Steel, R., and Frostick, L., eds., Tectonic controls and signatures in sedimentary successions: Oxford, Blackwell Scientific Publications, International Association of Sedimentologists Special Publication No. 20, p. 377-397.

Belt, E. S., Flores, R. M., Warwick, P. D., Conway, K. M., Johnson, K. R., and Waskowitz, R. S., 1984, Relationship of fluviodeltaic facies to coal deposition in the lower Fort Union Formation (Paleocene), southwestern North
Dakota: Oxford, Blackwell Scientific Publications, International Association of Sedimentologists Special Publication No. 7, p. 177-195.

Belt, E. S., Groenewold, G. H., Stevenson, R. J., and Schmit, C. R., 1985, Clay mineralogical variations in the Paleocene of the Williston Basin [abs.]: Society of Economic Paleontologists and Mineralogists, Mid-year Meeting, v. 2, p. 10.

Belt, E. S., Sakimoto, S. E. H., and Rockwell, B. W., 1992, A drainage diversion hypothesis for the origin of widespread coal beds in the Williston Basin: Examples from Paleocene strata, eastern Montana, in Sholes, M. A., ed., Coal geology of Montana: Montana Bureau of Mines and Geology Special Publication No. 102, p. 21-60.

Belt, E. S., Hicks, J. F., and Murphy, D. A., 1997, A pre-Lancian regional unconformity and its relationship to Hell Creek paleogeography in southeastern Montana: Contributions to Geology, University of Wyoming, v. 33, p. 1-26.

Belt, E. S., Diemer, J. A., Vuke, S. M., Beutner, E. C., and Cole, B. S., 2002, The Ekalaka Member of the Fort Union Formation, southeastern Montana: Designating a new member and making a case for estuarine deposition and bounding unconformities: Montana Bureau of Mines and Geology Open-File Report No. 461, 56 p.

Belt, E. S., Tibert, N. E., Curran, H. A., Diemer, J. A., Hartman, J. H., Kroeger, T. J., and Harwood, D. M., submitted, Evidence for marine influence on a low-gradient coastal plain: Ichnology and invertebrate paleontology of the lower Tongue River Member (Fort Union Formation, middle Paleocene), western Williston Basin, U.S.A.: Rocky Mountain Geology.

Bergantino, R. N., 1980, Geologic map of the Ekalaka $1^{\circ} \times 2^{\circ}$ quadrangle, southeastern Montana: Montana Bureau of Mines and Geology, Montana Atlas Map MA 1-A, scale $1: 25,000$.

Berggren, W. A., Kent, D. V., Swisher, C. C., III, and Aubry, M.-P., 1995, A revised Cenozoic geochronology and chronostratigraphy, in Berggren, W. A., Kent, D. V., Aubry, M.-P., and Hardenbol, J., eds., Geochronology time scales and global stratigraphic correlation: Tulsa, SEPM (Society for Sedimentary Geology) Special Publication 54, p. 129212.

Cherven, V. B., and Jacob, A. F., 1985, Evolution of Paleogene depositional systems, Williston Basin, in response to global sea level changes, in Flores R. M., and Kaplan, S. S., eds., Cenozoic paleogeography of the west-central United States: Denver, Rocky Mountain Section of the Society of Economic Paleontologists and Mineralogists, Rocky Mountain Paleogeography Symposium 3, p. 127-170.

Christiansen, K. C., 1984, The stratigraphy and petrography of a light-colored siliceous horizon within the Fort Union Formation (Paleocene), southeastern Montana [Master's 
thesis]: Butte, Montana College of Mineral Science and Technology, $183 \mathrm{p}$.

Clayton, L., Carlson, C. G., Moore, W. L., Groenewold, G., Holland, F. D., Jr., and Moran, S. R., 1977, The Slope (Paleocene) and Bullion Creek (Paleocene) Formations of North Dakota: North Dakota Geological Survey Report of Investigation No. 59, $14 \mathrm{p}$.

Clement, J. H., 1986, Cedar Creek: A significant paleotectonic feature of the Williston Basin: Tulsa, American Association of Petroleum Geologists Memoir 41, p. 213-240.

Conway, K. M., 1982, Sedimentology of fluvial facies in the Upper Ludlow and Lower Tongue River Members of the Fort Union Formation (Paleocene), southwestern North Dakota [Bachelor's thesis]: Amherst, Massachusetts, Amherst College, 129 p.

Cvancara, A. M., 1965, Bivalves and biostratigraphy of the Cannonball Formation (Paleocene) in North Dakota [Ph. D. dissert.]: Ann Arbor, University of Michigan, 470 p.

1976, Geology of the Cannonball Formation (Paleocene) in the Williston Basin, with reference to uranium potential: North Dakota Geological Survey Report of Investigation 57, 22 p.

Daly, D. J., Sholes, M. A., and Schmit, C. R., 1992, Geology and depositional environments of the coal-bearing strata of the Fort Union lignite region, in Finkelman, R. B., Tewalt, S. J., and Daly, D. J., eds., Geology and utilization of Fort Union lignites: U.S. Geological Survey, Reston, Virginia, Environmental and Coal Associates, p. 3-51.

Diemer, J. A., and Belt, E. S., 1991, Sedimentology and paleohydraulics of the meandering river systems of the Fort Union Formation, southeastern Montana: Sedimentary Geology, v. 75, p. 85-108.

Flores, R. M., Keighin, C. W., Ochs, A. M., Warwick, P. D., Bader, L. R., and Murphy, E. C., 1999, Framework geology of Fort Union coal in the Williston Basin, in Fort Union Assessment Team, 1999 Resource assessment of selected Tertiary coal beds and zones in the northern Rocky Mountains and Great Plains region: U.S. Geological Survey Professional Paper 1625-A, Chapter WF, 27 p.

Gill, J. R., 1959, Reconnaissance for uranium in the Ekalaka lignite field, Carter County, Montana: U.S. Geological Survey Bulletin 1055-F, p. 167-179.

Hardenbol, J., Thierry, J., Farley, M. B., Jacquin, T., de Graciansky, P.-C., and Vail, P. R., 1998, Mesozoic and Cenozoic sequence stratigraphy of European basins, in Graciansky, P.-C., Hardenbol, J., Jacquin, T., and Vail, P. R., eds., Mesozoic and Cenozoic sequence chronostratigraphic framework of European basins: Tulsa, SEPM (Society for Sedimentary Geology) Special Publication 60, p. 3-13, with Appendix, p. 763-781.

Hartman, J. H., 1989, The T-Cross coal bed (Paleocene, North Dakota): The importance of re-evaluating historic data in geologic research: North Dakota Academy of Science Proceedings, v. 43, p. 49.

1993, The type areas of the Paleocene Slope Formation and intercalated tongues of the Cannonball Formation, Slope County, North Dakota, in Kihm, A. J., and Hartman, J. H., eds., The Marshall Lambert Symposium: Bowman, North Dakota, North Dakota Geological Society (Pioneer Trails Museum, June 19-20, 1993), p. 78-86.

Hartman, J. H., and Butler, R. D., 1995, Extinction and recovery of nonmarine molluscan assemblages in the Late Cretaceous and early Tertiary: Geological Society of America (Rocky Mountain Section), Abstracts with Programs, v. 27, no. 4, p. 13.

Hartman, J. H., and Kihm, A. J., 1992, Chronostratigraphy of Paleocene strata in the Williston Basin, in Finkelman, R. B., Daly, D. J., and Tewalt, S. J., eds., Geology and utilization of Fort Union lignites: U.S. Geological Survey, Reston, Virginia, Environmental and Coal Associates, p. $52-75$.

1996, Bio- and magnetostratigraphy of the uppermost Cretaceous and lower Tertiary strata of North Dakota, in Pepetski, J. E., ed., Washington, DC, $6^{\text {th }}$ North American Paleontological Convention Abstracts of Papers, Paleontological Society Special Publications, no. 8, p. 163.

Hartman, J. H., and Kirkland, J. I., 2002, The brackish and marine mollusks of the Hell Creek Formation, North Dakota: Evidence for a persisting seaway, in Hartman, J. H., Johnson, K. R., and Nichols, D. J., eds., The Hell Creek Formation and the Cretaceous-Tertiary boundary in the northern Great Plains: An integrated continental record of the end of the Cretaceous: Geological Society of America Special Paper 361, p. 271-296.

Heffern, E. L., 1981, Terry Badlands WSA-684: Miles City, Montana, U.S. Bureau of Land Management unpublished Report, 12 p.

Hicks, J. F., Johnson, K. R., Obradovich, J. D., Tauxe, L., and Clark, D., 2002, Magnetostratigraphy and geochronology of the Hell Creek and basal Fort Union Formations of southwestern North Dakota and a recalibration of the age of the Cretaceous-Tertiary boundary, in Hartman, J. H., Johnson, K. R., and Nichols, D. J., eds., The Hell Creek Formation and the Cretaceous-Tertiary boundary in the northern Great Plains: An integrated continental record of the end of the Cretaceous: Geological Society of America Special Paper 361, p. 35-56.

Hoganson, J. W., and Murphy, E. C., 2002, Marine Breien Member (Maastrichtian) of the Hell Creek Formation in North Dakota: Stratigraphy, vertebrate fossil record, and age, in Hartman, J. H., Johnson, K. R., and Nichols, D. J., eds., The Hell Creek Formation and the CretaceousTertiary boundary in the northern Great Plains: An inte- 
grated continental record of the end of the Cretaceous: Geological Society of America Special Paper 361, p. 247270.

Hunter, J. P., 1999, The radiation of Paleocene mammals with the demise of the dinosaurs: Evidence from southwestern North Dakota: North Dakota Academy of Sciences Proceedings v. 53, p. 141-143.

Krause, D. W., 1987, Baiotomeus, a new ptilodontid multituberculate (Mammalia) from the middle Paleocene of western North America: Journal of Paleontology, v. 61, p. 595603.

Kroeger, T. J., 1995, The paleoecologic significance of Paleocene palynomorph assemblages from the Ludlow, Slope and Cannonball Formations, southwestern North Dakota [Ph. D. dissert.]: Grand Forks, University of North Dakota, 389 p.

Kroeger, T. J., and Hartman, J. H., 1997, Paleoenvironmental distribution of Paleocene palynomorph assemblages from brackish water deposits in the Ludlow, Slope, and Cannonball Formations, southwestern North Dakota: Contributions to Geology, University of Wyoming, v. 32, p. 115-129.

Lund, S. P., Hartman, J. H., and Banerjee, S. K., 2002, Magnetostratigraphy of interfingering Upper CretaceousPaleocene marine and continental strata of the Williston Basin, North Dakota and Montana, in Hartman, J. H., Johnson, K. R., and Nichols, D. J., eds., The Hell Creek Formation and the Cretaceous-Tertiary boundary in the northern Great Plains region: An integrated continental record of the end of the Cretaceous: Geological Society of America Special Paper 361, p. 57-74.

Matson, R. E., and Blumer, J. W., 1973, Quality and reserves of strippable coal, selected deposits, southeastern Montana: Montana Bureau of Mines and Geology Bulletin 91, 135 p.

Nichols, D. J., 1998, Palynostratigraphy of the Fort Union Formation (Paleocene) in the North Dakota part of the Williston Basin and its application to coal resource assessment: Geological Society of America Abstracts with Programs, v. 30, no. 7, p. 366.

2003, Palynostratigraphic framework for age determination and correlation of the nonmarine lower Cenozoic of the Rocky Mountains and Great Plains region, in Raynolds, R. G, and Flores, R. M., eds., Cenozoic systems of the Rocky Mountain region: Denver, Colorado, Rocky Mountain Section of the Society for Sedimentary Geology (SEPM), p. 107-134.

Obradovich, J. D., 2002, Geochronology of Laramide synorogenic strata in the Denver Basin, Colorado: Rocky Mountain Geology, v. 37, p. 165-171.

Obradovich, J. D., and Hicks, J. F., 1999, A review of the isotopic calibration points for the geomagnetic polarity time scale in the interval 83 to $33 \mathrm{Ma}(\mathrm{C} 34 \mathrm{~N}$ to $\mathrm{C} 13 \mathrm{~N})$ : Geological Society of America Abstracts with Programs, v. 31, no. 7, p. 71.

Parker, F. S., and Andrews, D. A., 1939, The Mizpah coal field, Custer County, Montana: U.S. Geological Survey Bulletin 906-C, p. 85-133.

Prothero, D. R., 1995, Geochronology and magnetostratigraphy of Paleogene North American land mammal "ages": An update, in Berggren, W. A., Kent, D. V., Aubry, M.-P., and Hardenbol, J., eds., Geochronology, time scales and global stratigraphic correlation: Tulsa, SEPM (Society for Sedimentary Geology) Special Publication 54, p. 305315.

Sholes, M. A., 1988, Coal resources of the Baker and Wibaux 30 x 60-minute quadrangle, eastern Montana and adjacent North Dakota: Montana Bureau of Mines and Geology Geologic Map Series No. 48, scale 1:100,000, 8 pages of notes.

Sholes, M. A., Vuke-Foster, S. M., and Derkey, P. D., 1989, Coal stratigraphy and correlation in the Glendive 30 x 60 minute quadrangle, eastern Montana and adjacent North Dakota: Montana Bureau of Mines and Geology Geologic Map Series No. 45, 4 sheets, scale: 1:100,000, 9 pages of notes.

Simon-Coinçon, R., Milnes, A. R., Thiry, M., and Wright, M. J., 1996, Evolution of landscapes in northern South Australia in relation to the distribution and formation of silcretes: Journal of the Geological Society, London, v. 153, p. 467-480.

Strait, S. G., and Krause, D. W., 1988, New Paleocene fossils from the Crazy Mountains, Montana: Implications for plesiadapid (Mammalia, ?Primates) systematics and biochronology [abs.]: Journal of Vertebrate Paleontology, v. 8, suppl. to no. 3, p. 27A.

Tibert, N. E., Curran, H. A., Hartman, J. H., Belt, E. S., and Diemer, J. A., 2001, Marine flooding intervals within the freshwater Tongue River Member (Fort Union Formation - Paleocene), western Williston Basin [abs.]: Denver, American Association of Petroleum Geologists Annual Convention, June 3-6, 2001, Official Program Book, p. 200.

Van Alstine, J. B., 1974, Paleontology of brackish-water faunas in two tongues of the Cannonball Formation (Paleocene, Danian), Slope and Golden Valley Counties, southwestern North Dakota [Master's thesis]: Grand Forks, University of North Dakota, $101 \mathrm{p}$.

Vuke, S. M., and Belt, E. S., 1995, Early Paleocene uplift of the Black Hills and Miles City arch: Geological Society of America Abstracts with Programs, v. 27, no. 4, p. 59.

Vuke, S. M., and Colton, R. B., 2003, Geologic map of the Terry 30 x 60 minute quadrangle, eastern Montana: Montana Bureau of Mines and Geology Open-File Report 477, 9 p., scale 1:100,000. 
Vuke, S. M., Wilde, E. M, Colton, R. B., and Stickney, M. C., 2001, Geologic map of the Baker 30 x 60 minute quadrangle, eastern Montana: Montana Bureau of Mines and Geology Open-File Report 427, 9 p., scale 1:100,000.

Warwick, P. D., 1982, Geology of some lignite-bearing fluvial deposits (Paleocene), southwestern North Dakota [Master's thesis]: Raleigh, North Carolina State University, 116 p.

Warwick, P. D., and Luck, K. R., 1995, Stratigraphic sections of the lignite-bearing Tongue River Member, Fort Union Formation (Paleocene), southwestern North Dakota: U.S. Geological Survey Open-File Report 95-676, 39 p.

Warwick, P. D., Flores, R. M., Murphy, E. C., and Obradovich, J. D., 1995, Parasequences in the Paleocene Ludlow and Cannonball Members of the Fort Union Formation, Williston Basin, North Dakota: Geological Society of American Abstracts with Programs, v. 27, no. 4, p. 60.

Warwick, P. D., Flores, R. M., Nichols, D. J., and Murphy, E. C., 2004, Chronostratigraphic and depositional sequences of the Fort Union Formation (Paleocene), Williston Basin, North Dakota, South Dakota, and Montana, in Pashin, J. C., and Gastaldo, R. A., eds., Sequence stratigraphy, paleoclimate, and tectonics of coal-bearing strata: Tulsa, American Association of Petroleum Geologists Studies in Geology 51, p. 121-145.

Wehrfritz, B. D., 1978, The Rhame Bed (Slope Formation, Paleocene), a silcrete and deep-weathering profile in southwestern North Dakota [Master's thesis]: Grand Forks, University of North Dakota, 143 p.

Winczewski, L. M., and Groenewold, G. H., 1982, A tectonic-fluvial model for Paleocene coal-bearing sediments, Williston basin, southwestern North Dakota, in Gurgel, K. D., ed., Fifth symposium on the geology of Rocky Mountain coal: Utah Geological and Mineralogical Survey Bulletin 118, p. 76-88.

ManusCript Submitted July 5, 2003

Revised Manuscript Submitted July 8, 2004

Manuscript ACCePted November 5, 2004 
Appendix 1. Locations of measured sections cited in text.

Code numbers used for measured sections are keyed to locality and author of section (e.g., in 1981 field season on Little Missouri River, letters B, C, J, and W, referred to Belt, Conway, Johnson, and Waskowitz, respectively). In early publication (Belt et al., 1984), the code was simple: B-1, B-2, or C-1, C-2. Later (Belt et al., 1992), B-1, B-2, R-1, and R-2 were used in Pine Hills study area. In present report, because we summarize so many different field areas, code for each measured section is prefaced by an acronym indicating that area. The LMR, PH, TB, SB, and $\mathrm{E}$ symbols (see below) preface local section numbers for each area. In some instances, a section-measuring date is added (e.g., SB-B-1'97).

\section{(1) Little Missouri River, North Dakota (LMR, Figs. 1 and} 8-10).

Locations of some of the following sections are shown by Belt et al. (1984, figs. 4 and 5). LMR-B- sections are largely from unpublished field notes (E. S. Belt, 19812002); LMR-C-9 section is from a thesis by Conway (1982). Unpublished field notes of J. H. Hartman, (19891992) also were used. Sections occur on the following 7.5' quadrangles: Spring Creek, Dry Bullion Creek, Three V Crossing, Deep Creek North, Boyce Creek West, Williams Lake, and Pretty Butte.

\section{List of measured sections:}

LMR-B-103: Sec. 3, NW 1/4, T. 136 N., R. 104 W. LMR-B-102: Sec. 36, SW 1/4, T. 137 N., R. 104 W. LMR-B-101: base is $100 \mathrm{~m}$ SW of base of Section LMR$\mathrm{B}-12$ (see below); this section trends $\mathrm{N}$.

LMR-B-100A: top at LONG $103^{\circ} 42^{\prime} 29.35^{\prime \prime} \mathrm{N}, \mathrm{LAT} 46^{\circ}$ 38' 43.69" N.

LMR-B-100: base at LONG $103^{\circ} 42^{\prime} 42.99^{\prime \prime}$ W, LAT $46^{\circ}$ $38^{\prime} 9.43^{\prime \prime} \mathrm{N}$.

LMR-B-67: Sec. 36, SE 1/4, T. 137 N., R. 104 W., and Sec. 31, SW 1/4, T. 137 N., R. 103 W.

LMR-B-66: Sec. 9, NE 1/4, T. 137 N., R. 103 W.

LMR-B-65: Sec. 31, south-central part, T. 137 N., R. 103 $\mathrm{W}$.

LMR-B-56: Sec. 8, north central edge, T. 136 N., R. 102 W. LONG $103^{\circ} 31.268^{\prime} \mathrm{N}$, LAT $46^{\circ} 36.852^{\prime} \mathrm{W}$.

LMR-B-44: middle of boundary between Secs. 8 and 9, T. 135 N., R. 105 W. (see Belt et al., 1984, fig. 6). LMR-B-40: Sec. 12, SW 1/4, T. 135 N., R. 105 W. (see Belt et al., 1984, fig. 5).
LMR-B-15: Sec. 20, SE 1/4, T. 136 N., R. 104 W. (see Belt et al., 1984, fig. 5).

LMR-B-14: Sec. 6, NE 1/4, T. 136 N., R. 103 W. (see Belt et al., 1984, fig. 7).

LMR-B-12: base at Little Missouri River, Sec. 31, southcentral part, T. 137 N., R. 103 W. (see Belt et al., 1984, fig. 5).

LMR-B-10: base at river, Sec. 10, NE 1/4, T. 136 N., R. 104 W. (see Belt et al., 1984, fig. 5).

LMR-C-9: starting at base of cliff, Sec. 4, SE 1/4, T. 136 N., R. 104 W. (see Conway, 1982).

(2) Localities of measured sections from badlands north of Terry, Montana (TB, Figs. 1 and 3).

Previous mapping in this area was by Heffern (1981) and Vuke and Colton (2003). Belt was assisted by E. L. Heffern in 1982, by J. A. Diemer in 1997, and by N. E. Tibert in 1999. Sections measured in 2001 were with T. J. Kroeger.

List of measured sections:

Section Terry I ('82): top lies in clinker, Sec. 1, NE 1/4, T. 12 N., R. 50 E.

Section Terry II ('97): base below road level, Sec. 34, SW 1/4 of SE 1/4, T. 13 N., R. 50 E., extends to clinker at top of butte.

Mushroom Café Section ('01): LONG $105^{\circ} 21.743^{\prime} \mathrm{W}$, LAT $46^{\circ} 50.124^{\prime} \mathrm{N}$.

Paleovalley Section ('01): base at $45 \mathrm{~m}$ below road level, $643 \mathrm{~m}$ due west of top of Terry II Section.

Snail Gorge Section ('01): base at $10 \mathrm{~m}$ below road level, $320 \mathrm{~m}, \mathrm{NW}$ of top of Terry II Section.

Terry/Bridge Section ('99): top of section at Radio Tower indicated on 7.5' Terry quadrangle, Sec. 9, NE 1/4, T. 12 N., R. 51 E., base of section at C-coal in a drainage below highway level.

(3) Pine Hills study area, near Locate, Montana (PH, Fig. 1).

These sections were used by Belt et al. (1992). All but PHB-56 lie in SE quarter of Buck Mountain 7.5' quadrangle, Montana. PH-B-56 lies in the Locate SW quadrangle.

List of measured sections:

PH-B-56: Sec. 24, SE corner, T. 7 N., R. 50 E., on South Laney Creek.

PH-B-43: Sec. 36, NW 1/4, T. 8 N., R. 50 E. 
PH-B-42: Sec. 1, NE 1/4, T. 7 N., R. 50 E.

PH-B-33: Sec 12, SW 1/4, T. 7 N., R. 50 E.

PH-B-31: Sec. 1, SW 1/4, T. 7 N., R. 50 E.

(4) Signal Butte sections, Miles City, Montana (SB, Fig. 1).

These sections were measured by Belt, who was assisted in 1982 by E. L. Heffern, in 1997 by J. A. Diemer, and in 1999 by N. E. Tibert. Clinker underlies Radio Towers on Miles City, 7.5' quadrangle.

List of measured sections:

SB-I (1982): base at C-coal, top at Tongue River clinker, Sec. 5, NW 1/4, T. 7 N., R. 48 E., northern side of Signal Butte.

SB-II (1997): base at upper Lebo D-coal, top at Tongue River clinker, eastern approach to Signal Butte, base lies mid-boundary between sections 6 (west) and 5 (east).

SB-III (1999): base at C-coal, top in lower D-coal zone, center of Sec. 6, T. 7 N., R. 48 E.

\section{Appendix 2. Data relevant to palynomorphic biozones.}

\section{(A) Palynomorphic species and their biozones.}

Stratigraphic ranges of genera and/or species indicated here and their interval-zone designations are based on Nichols (2003, p. 120-121, 126-130, and fig. 9). Also see Warwick et al. (2004, table 3) for biozones indicated at Hanson Ranch (Fig. 10).

Biozone P-5 (Caryapollenites veripites-Pistillipollenites mcgregorii Interval Zone):

Caryapollenites imparalis

Caryapollenites veripites (first occurrence)

Ericipites

Insulapollis

Ilexpollenites

Laevigatosporites

Momipites wyomingensis

Momipites triorbicularis

Pterocarya

Biozone P-4 (Momipites ventifluminis-Caryapollenites wodehousei Interval Zone):

No pollen assemblage defining this biozone was recognized by T. J. Kroeger from any Montana sections sampled (SB, PH, TB, Fig. 1); however, the entire P-4 pollen zone was identified by D. J. Nichols in $26 \mathrm{~m}$ of section at Hanson Ranch, or Rabbit Ears Butte (Fig. 10; Warwick et al., 2004, table 3).
List of pollen species given below came from D. J. Nichols (e-mail communication, January 26, 2004). Specimens came from sample BT99-33, section LMR-C-9, unit 16. This is the top coal shown in section LMR-C-9, Figure 8 and is the Harmon coal bed, which correlates to the Hanson Ranch (Fig. 9) $16 \mathrm{~km}$ to the east of section LMRC-9.

Alnipollenites scoticus

Caryapollenites wodehousei (first occurrence)

Insulapollenites rugulatus

Momipites actinus

Momipites amplus

Momipites anellus

Momipites triorbicularis

Momipites ventifluminis

Momipites wyomingensis

Biozone P-3 (Momipites actinus-Aquilapollenites spinulosus Interval Zone):

Most common biozone encountered in Montana. List is a combination of those species recognized by T. J. Kroeger and D. J. Nichols from our Montana samples.

Alnipollenites scoticus (first occurrence)

Alnipollenites speciipites

Aquilapollenites spinulosus (first occurrence)

Caryapollenites prodromus (first occurrence)

Erdtmanipollis

Fraxinopollinites vaeriabilus

Insulapollenites rugulatus (first occurrence)

Jazenipollenites trinus

Momipites actinus (first occurrence)

Momipites anellus (first occurrence)

Momipites leboensis (first occurrence)

Momipites leffingwelli

Momipites tenuipolis

Momipites ventifluminis (first occurrence)

Momipites waltmanensis

Momipites wyomingensis (first occurrence)

Retitrescolpites anguloluminosus

Retitrescollpites bathyreticulates

Taliisipites pluvifluminis

Tilia vescipites (first occurrence)

Biozones P-1 and P-2:

No pollen from these biozones was found in any of our Montana samples. It is reported from lower Ludlow strata on Little Missouri River, North Dakota (Warwick et al., 2004, table 3).

(B) Stratigraphic position of pollen biozones west of Cedar Creek anticline. 
Terry Badlands area (Fig. 3):

Four pollen samples from Tongue River Member (all above the unconformity) and one from Lebo Member (below the unconformity) were assigned to biozone P-3. Thus P-2/P-3 boundary lies within Lebo Member below the unconformity. Two volcanic ash samples, about $1 \mathrm{~km}$ apart, from top coal bed in D-coal zone (cf. Fig. 5) yielded ash dates 2 and 3 (Fig. 12), whose mean ages are 64.2 and 64.7 Ma, respectively. They occur about $20 \mathrm{~m}$ below top of Lebo Member, but pollen from associated coal beds was unidentifiable. 64.2 Ma ash is shown as va ${ }_{2}$ on Figure 11. On basis of these data, biozone P-3 persists through $53.5 \mathrm{~m}$ of Tongue River strata above the unconformity, provided an additional $42 \mathrm{~m}$ of paleovalley thickness is discounted (Fig. 3). Probably some unknown thickness of upper Lebo Member will turn out to be P-3 as well. Thickness of P3 Tongue River strata here will be useful for comparing thickness of P-3 strata of same lithology east of CCA in Little Missouri River (LMR) study area. Biozones P-4 and $\mathrm{P}-5$ were not found in these TB sections.

Pine Hills area (Figs. 5 and 6):

Contact coals and E-coals from Tongue River Member are assigned to pollen biozone $\mathrm{P}-3$ in sections $\mathrm{PH}-\mathrm{B}-33$ and PH-B-42 (Fig. 6). In PH-B-33, this includes $85 \mathrm{~m}$ of Tongue River strata above the unconformity, provided an additional $32 \mathrm{~m}$ of paleovalley thickness is discounted. In section PH-B-42, E-coals $58 \mathrm{~m}$ above basal burrow bed are assigned to biozone $\mathrm{P}-3$. Position of top of $\mathrm{D}$-coal zone in Figure 6 is same coal zone from which we obtained ash dates 2 and 3 (Fig. 12) in Terry Butte area. D-coals were not analyzed for pollen. D-coal zone predictably would be biozone P-2. Biozones P- 4 and P-5 were not found in these sections.

\section{Signal Butte area (Figs. 1 and 2):}

Lowest $26 \mathrm{~m}$ of Tongue River Member contains two coal beds, one at $10 \mathrm{~m}$ and another at $25 \mathrm{~m}$ above basal contact. Both have been assigned to pollen biozone P-3. Coal beds in strata above this level yielded no pollen. Four $\mathrm{m}$ below Lebo-Tongue River contact, pollen from a Lebo coal was designated biozone P-3. Twenty-eight $\mathrm{m}$ below contact, a volcanic ash from a coal bed yielded a date of $64.56 \pm 0.43$ (ash date 1, Fig. 12), shown as va ${ }_{1}$ on Figure 11. This coal was assigned to pollen biozone P-3. The ash date makes it older than P-2/P-3 boundary of 64.4 $\pm 1.8 \mathrm{Ma}$ proposed by Nichols (1998) and thus would be expected to be P-2 biozone. A 64.0 Ma date for P-2/P-3 boundary was suggested on basis of a $64.1 \pm 0.9 \mathrm{Ma}$ date from a coal containing P-2 pollen in Ekalaka area (Belt et al., 2002, p. 35). Is the P-2/P-3 boundary time-transgressive on a regional basis? We recommend that $\mathrm{P}-2$ to $\mathrm{P}-3$ be a transition of ca. $0.5 \mathrm{Ma}$ centered on $64.4 \pm 0.25 \mathrm{Ma}$, as shown in Figure 11. Biozones P- 4 and P-5 were not found in these sections.

\section{(C) Stratigraphic position of pollen biozones east of Cedar} Creek anticline.

\section{Little Missouri River area (Figs. 8-10):}

Biozones from Tongue River Member east of CCA all come from LMR area. Pollen biozone P-3 is confined to lower $14 \mathrm{~m}$ of Tongue River strata (sections LMR-B-100 and LMR-B-56, Figs. 8 and 9) above the unconformity. P-3 designation is supported by a new isotopic date from $\mathrm{H}$-coal bed at section LMR-B-56 (ash date 7, Fig. 12, and Appendix 3). This date is $61.06 \pm 0.33 \mathrm{Ma}$, and it corresponds well with published date of $61.23 \pm 0.38 \mathrm{Ma}$ reported by Warwick et al. $(1995,2004)$ from same coal in H-coal zone (ash date 6, Fig. 12). P-3 to P-4 transition lies within $3 \mathrm{~m}$ of rooty silts and muds between Hanson and Harmon coal beds (sections LMR-B-100, LMR-B-56 in Figs. 8 and 9). P-4/P-5 transition lies in $8 \mathrm{~m}$ of strata between upper coal (P-5) and lower unnamed coal (P-4) shown in Figure 9, section LMR-B-56. Upper unnamed coal is also P-5 in LMR-B-100A (Don Engelhardt, personal communication, 1999). P-3 biozone is found in upper Ludlow strata from top of Rhame zone at the unconformity, into older strata to just above Oyster coal bed that underlies Three VTongue of the Cannonball Member (va ${ }_{3}$, Fig. 11), where P-2/P-3 boundary occurs (Nichols, 2003; Warwick et al., 2004). Sections LMR-B-40 and LMR-B-44 (Belt et al., 1984, figs. 5 and 6, respectively) show proper stratigraphic relationships. This position corresponds to a major change in pollen assemblages noted by Kroeger (1995). As mentioned above, P-2/P-3 transition would be a ca. 0.5 million year zone centered on 64.4 Ma.

\section{Appendix 3. Information relevant to radiometric dates.}

Ash dates 4, 5, and 6 in Figure 12 are based on analyses conducted in John D. Obradovich's Denver Laboratory (Vuke and Belt, 1995; Warwick et al., 1995; Nichols, 1998, 2003). Ash dates 1, 2, 3, 7, and 8 are based on analyses run in Bruce Idleman's Lehigh Laboratory. Figure 12 adopted recalibrated K-Tboundaryaccording to Hicksetal.(2002), Obradovich and Hicks (1999), and Obradovich (2002).

Discussion of dates derived from volcanic ash.

(1) Little Missouri River area: 
(A) An ash bed within $\mathrm{H}$-coal bed overlying Rhame bed at Hanson Ranch (Fig. 9) has an ${ }^{40} \mathrm{Ar} /{ }^{39} \mathrm{Ar}$ age of $61.23 \pm 0.38 \mathrm{Ma}$ (Warwick et al., 1995, 2004). It was used by Nichols $(1998,2003)$ to determine the P-3/P-4 transition. It is shown as $\mathrm{va}_{4}$ on Figure 11 and as item 6 on Figure 12. A volcanic ash from same $\mathrm{H}$-coal bed at Hanson Ranch within our LMR-B-56 section (Fig. 9, section measured in 1983) was sampled in 2003 and run in Idleman Laboratory. Weighted mean age using ${ }^{40} \mathrm{Ar} /{ }^{39} \mathrm{Ar}$ method is $61.06 \pm 0.33 \mathrm{Ma}$. Although precise location of Warwick et al. (1995) sample is unknown, we are confident that our ash bed is at same horizon as theirs, confirming Obradovich's published date.

(B) An ash bed with ${ }^{40} \mathrm{Ar} /{ }^{39} \mathrm{Ar}$ age of $64.4 \pm 1.8 \mathrm{Ma}$ is reported from $2 \mathrm{~m}$ above Oyster coal bed (Warwick et al., 1995). It was used by Nichols $(1998,2003)$ to determine the P-2/P-3 transition. It is shown as va ${ }_{3}$ on Figure 11 and as item 5 on Figure 12.

\section{(2) Terry Badlands area:}

Two ash beds were collected from a coal in upper D-coal zone of Lebo Member, at approximately $20 \mathrm{~m}$ below Hi. D. burrow bed that defines regional base of Tongue River Member (Fig. 3). "Ash III" has an age of $64.21 \pm 0.37 \mathrm{Ma}$ $\left({ }^{40} \mathrm{Ar} /{ }^{39} \mathrm{Ar}\right.$, Idleman Laboratory, Lehigh University Noble Gas Lab., 1999). It is located at LONG 46 $50^{\prime} 9.2^{\prime \prime} \mathrm{W}$, LAT $105^{\circ} 21^{\prime} 43.9^{\prime \prime} \mathrm{N}$. "Ash II" has an age of $64.73 \pm 0.7$ Ma. It is located at NW 1/4 Sec. 6, T. 12 N., R. 51 E. at a position $402 \mathrm{~m}$ south of base of Mushroom Café Section (see Appendix 1).

"Ash III" is shown as va ${ }_{2}$ on Figure 11, and as item 3 on Figure 12.

\section{(3) Signal Butte area:}

"Ash I" was sampled from a coal bed in upper Lebo Member, $28 \mathrm{~m}$ below basal burrow bed of Tongue River Member in section SB-II. This ash has a ${ }^{40} \mathrm{Ar} /{ }^{39} \mathrm{Ar}$ date of $64.56 \pm 0.43 \mathrm{Ma}$ (Idleman, Lehigh University Noble Gas Lab, 1999). Ash I was located at LONG 46 23' 18.7" W, LAT $105^{\circ} 45^{\prime} 25.0^{\prime \prime} \mathrm{N}$. It is shown as va ${ }_{1}$ on Figure 11 and as ash date 1 on Figure 12. All samples processed in Lehigh Laboratory were run in triplicate using aliquots of 15 to 20 Fisher Canyon sanidine crystals per analysis. Aliquots were fused in one step with a Merchantek dual $\mathrm{UV} / \mathrm{CO} 2$ laser.

\section{(4) Southeastern Montana:}

(A) An ash bed from "Big Dirty" coal bed correlated by
Warwick et al. (1995) to the T-Cross coal bed and attributed to be from "southeastern Montana" is, in fact, from Bull Mountains in west-central Montana (Warwick et al., 2004). Bull Mountains lie outside of Williston Basin and are approximately $450 \mathrm{~km}$ west of type section of T-Cross coal bed on Little Missouri River, Slope County, ND. The only mineable coal beds in southeastern Montana are in Ekalaka lignite field of Carter County, where several thick coals are reported (but not the T-Cross coal bed; Gill, 1959). From surface and subsurface data in North Dakota, Belt et al. (1984, fig. 9) and Hartman (1989) found that T-Cross coal bed was confined to within 10 $\mathrm{km}$ west of Little Missouri River in southwestern North Dakota and that it could not be correlated in subsurface to north of X-X Ranch (Fig. 10). "Big Dirty" ash bed of Warwick et al. (2004) has an ${ }^{40} \mathrm{Ar} /{ }^{39} \mathrm{Ar}$ age of $64.78 \pm 0.21$ Ma. That date relates reasonably well with "Ash II" (64.73 $\pm 0.7 \mathrm{Ma}$; mentioned above) from top coal of $\mathrm{D}$-coal zone in Terry Badlands but poorly with their T-Cross correlation, as published. Top coal bed of D-coal zone in Terry Badlands is well within Lebo Member. It is $76 \mathrm{~m}$ above top of C-coal zone that marks base of that member and top of underlying Tullock Member (Terry/Bridge section from Appendix 1 (2)). Warwick et al. (2004, fig. 2) show "Big Dirty" coal bed with its $64.78 \mathrm{Ma}$ ash in lower part of Tullock Member (mentioned here to warn against correlating coals for hundreds of kilometers).

(B) Belt et al. (2002, p. 35) used isotopic data from Ekalaka area to revise Nichols (1998) age of P-2/P-3 boundary (see Fig. 12, ash date 4). Nichols had placed the boundary at $64.4 \mathrm{Ma}$, and we suggested that it be revised to 64.0 Ma. Our revision was based on occurrence of P-2 pollen (identified by D. J. Nichols for S. M. Vuke) in a coal that contained a volcanic ash dated $64.0 \pm 0.19 \mathrm{Ma}$ by J. D. Obradovich and reported in Vuke and Belt (1995). But the P-2/P-3 boundary is really only known within a transitional interval of roughly 0.5 million years, centered on 64.4 Ma. We retain date of $64.4 \mathrm{Ma}$ for P-2/P-3 boundary. Best stratigraphic section for resolving P-2/P-3 problem is at Signal Butte, near Miles City, Montana. A thorough job of dating those strata (using magnetostratigraphy, radioisotopes, pollen, etc.) was to have been conducted during summer of 2004 by K. R. Johnson, D. J. Nichols, and J. F. Hicks. 